\title{
The Chinatown in Peru and the Changing Peruvian Chinese Community(ies) ${ }^{1}$
}

\author{
Isabelle Lausent-Herrera
}

\begin{abstract}
The Chinese quarter established in Lima shortly after the arrival in 1849 of Chinese indentured laborers, mainly from the Guangdong province, has gone through significant changes during its long history. Perhaps the more significant of these have occurred since the last two decades with a new influx of Chinese immigrants mostly of Fujian origin. Instead of reinforcing the Chinese community the coexistence of the old and new Chinese has led to fragmentation, competition and increasing social tension in the Chinese community in Peru, not least in redefining the Huiguan's role. Competition has intensified not only in terms of pricing but also looking for commercial space (stores and warehouses). Wholesale importers of Chinese manufactured goods, restaurateurs, hoteliers and spa managers have extended their businesses beyond the old limits of Lima's Chinatown. Does this spell the end of Chinatown or the beginning of multiple Chinese quarters?
\end{abstract}

\section{Keywords}

Lima's Chinatown, new Chinese immigration, Peru-China trade relations, Chinese entrepreneurs, Tusans (Tusheng)

The Chinese quarter of Lima, Peru, is little known to foreign visitors who are always surprised to find that there is a large community of Chinese and their descendants, the Tusans, ${ }^{2}$ among the Peruvian population. This Chinese quarter, situated at the heart of the capital, is the location of a market and a place of very busy commercial activity. It has become the symbol of the Peruvian melting pot since the Chinese community implanted itself there in the 1850s. During the last 160 years, it has been a big part of the history of the

Isabelle Lausent-Herrera is Researcher at the French National Research Center (CNRS). Her email address is lausent.herrera@gmail.com

${ }^{1}$ I am grateful to Lucy Chang Acat and Liliana Com for their generous help in guiding me inside Lima's Chinatown.

2 The term tusan (tusheng) is commonly used in Peru to designate the children of Chinese parents born in Peru as well as children born of a Chinese father and a Peruvian or mixed race mother. Restricted in use initially it now refers to three generations of Chinese ancestry. See Lausent-Herrera (2009b).

(C) Koninklijke Brill NV, Leiden, 2011

DOI: $10.1163 / 179325411 X 565416$

Also available online - brill.nl/jco 
Chinese in Peru. The most important events will be recalled here. But the most drastic change seems to be the one taking place now, i.e. a change in the ethnic and places of origin of the new Chinese immigrants and above all the appearance of new commercial practices linked to the boom of Chinese imports distributed in the Chinese quarter. The increase in imports and the new Chinese migratory flow are also at the origin of a spatial explosion of the activities of the Chinese and the tusans affecting the other districts of the capital. These two changes signify not only the quarter's entry into the era of globalization but have also impacted the old Chinese community traditionally represented by the quarter, its activities and its institutions.

\section{Lima's Chinese Quarter, One of the Oldest in Latin America ${ }^{3}$}

The first Chinese were brought to Peru in 1849 to replace the African slaves in the sugar plantations and the guano fields in the Chincha Islands, in addition to filling numerous jobs as artisans (carpenters, tanners, cigarette or mattress makers, and bakers) and as servants and cooks for the wealthy families in the capital. The status of the latter, under a five-year contract, was relatively privileged because they were given semi-liberty. This same liberty allowed them to rapidly start families and to be engaged in various street trades: peddlers, (hot water sellers, vendors of grilled peanuts or sesame paste), porters and street sweepers. At the beginning of the 1860s the luckiest were those already working as butchers or pastry cooks or in various jobs in little restaurants or fonda. ${ }^{4}$ The coolie trade which brought more than 100,000 single Chinese men to Peru lasted until 1874, the year of the signing of the Treaty of Friendship, Commerce and Navigation at Tianjin. Free immigration followed until 1909 when it became strictly regulated; it was prohibited in 1930 .

\footnotetext{
${ }^{3}$ The first Chinese coolies were brought into Cuba in 1847. The concentration of the first free Chinese and artisans began within a few commercial streets at the center of the capital, Havana. However, in Lima, the formation of the Chinese quarter was linked to the construction of the central market. The literature on the Chinese presence in Cuba does not allow us to date precisely the establishment of the Chinese quarter but it is likely that it was formed at the same time as Lima itself.

${ }^{4}$ Examination of different archives (el Archivo General de la Nación: AGN) sección Protocolos Notariales and the Registros Parroquiales (Archivo Arzobispal de Lima: AAL) shows that the first artisans and businesses occupying the perimeter of the market of La Concepción often lived with indigenous Peruvian women. This facilitated their move into the quarter and enabled other Chinese bachelors to profit from their privileged position.
} 
From 1854 many Chinese, free and fleeing, came and settled around the new market of La Concepción which was under construction (1851-1854) in a pleasant quarter near the historic center occupied by monasteries and colonial residences. ${ }^{5}$ A supply center of fresh produce for the capital, this totally transformed new quarter attracted the Chinese freed from their contracts as well as the runaways and mixed race street vendors. In 1854 the Municipal Archives revealed the first receipts for the rent of places in the market for the Chinese. Little by little the market became a center of attraction for the Chinese where they lived, met each other and established their most important associations and guilds.

\section{The Californian Influence}

At the end of the $1860 s^{6}$ the first Chinese merchants from California settled themselves in the La Concepción market quarter. The appearance of the great commercial houses for the import of Chinese and North American goods, like those of San Francisco, was no doubt the first major event in the history of the Chinese Quarter. These companies such as the Wing Fat Co., the Wo Chong Co., or the Wing On Chong Co. ${ }^{7}$ gave the quarter a new look. These businesses were the importers of Chinese manufactured products (crockery, silks, furniture, articles made of bamboo) and food (rice and products for Chinese cuisine). ${ }^{8}$ They set themselves up alongside the ateliers of shoemakers and milliners, small shops and drinking places (bodegas and pulperias), groceries and dry food businesses, and retailers of Chinese products, supplied

\footnotetext{
${ }^{5}$ In Lima there are only three small markets which are insufficient for the capital. The creation of a new market was decided in 1846 on the site on part of the land of the Convent of $\mathrm{La}$ Concepción in the "Barrios altos" quarter adjoining the quarter of the Cathedral which was occupied by religious orders such as the Convent of La Concepción, the Monastery of Santa Rosa, the Descalzas churches (the Franciscan order), and the wealthy Creole and Spanish families.

${ }^{6}$ In 1867 Quong Wing Far arrived in Callao as representative of the commercial house in San Francisco, Yun Wo On Co. (Ministerio de Relaciones exteriores: M.R.E, 8-15-K, 16-101867); other Chinese import houses followed, e.g. Wo Chong Co., Wing Fat Co., Pow On Co. and Kang Tung Co.

7 The Wing On Chong is a branch of the WingWo Sang founded in San Francisco. It was set up in Valparaiso, Chile and in Lima in 1872. In 1882 the parent company was registered in Hong Kong (AGN, Protocolos Notariales, Vivanco, T.1038, 19/12/1882).

${ }^{8}$ Before the arrival of the Chinese commercial companies, the foreign ships (American, English, French or German) imported into Peru rice, cloves, cinnamon and dried products necessary for the preparation of Chinese cuisine, particularly in the haciendas. The new Chinese importers increased the volumes and above all the diversity of the products introduced into Peru including hundred-year-old eggs, dried mushroom, canned vegetables, dried fish, etc.
} 
by the wholesalers of Capón Street. Afro-Peruvian washerwomen, indigenous soldiers, cigarette makers now lived in this quarter which was becoming proletarian. The Chinese rented small lodgings in modest workers' houses as well as rooms lined up one after another in the dead end streets (callejones), a kind of closed corridor between buildings. Some were also bakery workers, cooks making and selling pastries and Chinese dishes and, in the case of the Hakka people, they cut up meat and sold it to customers. A country slaughterhouse and a few chickens and pigs: this apparently gave the name "Capón"' to one of the streets running along the market, which rapidly became the symbol of the Chinese occupation of this quarter. The elegant store windows of the Wing On Chong stores with its signs and decorations imported from China, sold luxury products such as Chinese dishes, porcelain ornaments, furniture and ivories projecting another image of Chinese culture. The managers and stockholders of the powerful commercial companies as well as their employees from Hong Kong and California would, by their presence and their financial means, support the activities of the first institution ${ }^{10}$ formed recently within the quarter by the Chinese freed from their contracts.

\section{The Tonghuy Chongkoc or the Official Installment, 1886}

The second event marking a new stage in the life of the quarter came at the time of the occupation of the city of Lima by the Chilean troops between 1881 and 1883. In the Concepción market quarter, not yet called barrio chino by the Limeños, Chinese commercial activities increased and their social and cultural activities ${ }^{11}$ at the temples, fetes, opium dens and theaters became

${ }^{9}$ Name given to this street because there was an enclosure where pigs and other animals were neutered.

${ }^{10}$ Free or runaway, and looking for refuge with the Chinese employed in Lima, the former coolies found protection and work through the Agencias de Chinos. These agencies were apparently the first kinds of Chinese organization in Lima. They appeared before 1860 and preceded the first regional associations. The first formal associations appeared from 1867 in Callao, in Lima and in the north of the country. They multiplied and diversified in the 1870s all over the country, up to Amazonia (Lausent-Herrera 1991, 1996a and 1998). In Lima, the three most important ones were founded in 1867: the Company of Canton (Guangzhou), the Ku y Kang (Guganzhou) and the Tungshing (Tung Sing) for the Hakka population (see AHLM, Alcaldia, 13 March 1861 and El Comercio on 10 September 1869). The Hokkien association, then the Nam Hoy and the Pun Yui (both Cantonese) rented their premises outside the Chinese Quarter. The Tung Sing and the Nam Jog (Nam Hoy) were the first to buy land on the outskirt of the Chinese quarter, in the new lots of the Huerta Perdida in 1874 (AGN, Terán, T754: 525 and 619). See Lausent-Herrera $(2000,1994)$.

${ }_{11}$ The activities of the Chinese quarter were reported in the Peruvian newspapers and by foreign travelers. Among them, for the period 1874-1880, there were Camille Pradier-Fodéré 
more and more visible. Some coolies still in service ${ }^{12}$ to the great hacienda owners south of Lima, went to join the Chilean invasion army and indirectly participated in the siege of Lima. When they entered the capital, these same Chileans attacked the Chinese storekeepers in La Concepción market. ${ }^{13}$ This event showed the Chinese the necessity for unity to defend their rights and for some of them - to show that they were willing to integrate into Peruvian society. They created in 1881 an association, the Sociedad Colonial de Beneficencia China, backed by the Peruvian church ${ }^{14}$ and the political authorities. For others this initiative led them to create, in 1886, with the support of the first ambassador from China, Wong Kay Sam, a federate association, the Tonghuy Chongkoc, the powerful Chinese Charitable Society of Peru, This association was forced to remain in the background as the Chinese community was taken in hand by Zheng Zaoru, the Imperial Emissary in 1886, who placed it under the control of the Chinese legation ${ }^{15}$ and the great Chinese commercial houses which themselves had invested in the regional associations or huiguan, among them the Wing On Chong Co. This brought together the Chinese from the Nam Hoy district. The money collected allowed them to buy in 1886 the building housing the new association, the Tonghuy Chongkoc ${ }^{16}$ whose institutional structures were similar to those governing San Francisco's Chinatown, the Chinese Consolidated Benevolent Association (CCBA). The establishment of the Tonghuy Chongkoc marked the creation of a real community and the takeover of the quarter by the Chinese community. The association, located in Hoyos Street (Paruro Street) ${ }^{17}$ and facing Capón Street, rapidly became the symbol of the Chinese occupation of this quarter.

(1897: 79-80), Charles d'Ursel (1889: 271) and Charles Wiener (1880: 454-55). Among other things, the latter wrote, "This race was raising itself, making life sweet and agreeable, installing a little China in Lima." The authors described particularly the performances of the Chinese theater. On this theme, there is, in the work of Muñoz (2001: 142), the picture of an actor from Lima's Chinese theater dating apparently from 1875 . If this date is correct, it would move the arrival and influence of the Chinese in San Francisco to before 1867, the supposed year of the arrival of the first Chinese commerce in California. Moreover, the Delicias or Odéon theatre (Teatro Chino) was founded in 1869 (calle Rostro de la Huaquilla). It was replaced in 1886 by the Teatro Olimpo which existed until 1919 when it became the Teatro Ferrero.

${ }^{12}$ When war was declared, the hacienda owners held the majority of Chinese workers illegally, inflicting upon them humiliation and physical ill treatment.

${ }_{13}$ According to the inhabitants of Lima, when the Chileans entered the capital, they forgot the help given to them by the coolies and attacked the Chinese in this quarter, killing and holding them to ransom. For information on this theme, see H. Witt's diary (1987: 309, 311,319).

${ }^{14}$ It was also supported by His Eminence, Raimondi, Bishop of Hong Kong.

${ }^{15}$ Legation headed by Lui Fuquian: first Chinese Consul in Lima-Callao and the first recognized President of the Association.

${ }^{16}$ Bilu zhonghua tonghui zongju yu bilu huaren (1886-1986), 1990, 55-56, Hong Kong.

${ }^{17}$ In the 1860s each block had a specific name. Only in the 1930s did the streets have the 


\section{Destruction and Restrictions: 1909-1930}

This tranquil, hardworking Chinese quarter is not the one projected in either the municipal reports or the newspapers. The elite, armed with notions of hygiene and influenced by three decades of Darwinian thought, harshly criticized the Chinese and the central market quarter which had become "their quarter" with its opium dens and gaming rooms, and condemned the depravity in which the Chinese lived. At the end of the war between Peru and Chili (1879-1894), the quarter was in a bad condition as it had suffered particularly from the demands of the Chilean occupants. Badly kept, the constructions were deteriorating and standard of hygiene, with the increasing number of inhabitants, was becoming poorer and poorer, particularly in the Otayza Passage facing the central market and another building, El Pescante. Cisneros and Garcia described this place in $1898^{18}$ in extremely harsh terms reminiscent of the first European racist ideologies. At the same time the outbreak of yellow fever in Lima added to the misery in the populous quarters. New epidemics swiftly followed. The existence of the Chinese quarter, this "bubo" in the heart of the city, was by itself enough to inject this fear into the hearts of the people. The ruined market was emptied of its merchants, its rents everywhere too high, the street vendors out of control, invading the squares of the neighboring streets in increasing frequency. Only a few great enterprises, Italian or Chinese, such as the commercial companies, Wing On Chong and Pow Lung, survived this crisis. ${ }^{19}$ They took the opportunity to take over the sites left vacant to increase the number of their warehouses and outlets, this in view of an economic recovery. This resilience in the face of crisis and the near control of the distribution of the products much needed by the smallscale Chinese shopkeepers poisoned the relations between Chinese and Peruvians.

In view of the growing hostility toward the Chinese and the inability of the Peruvian authorities to control the increasing numbers of incoming new

\footnotetext{
same name from one end to the other. The Capon Street is an extension of the two blocks on Ucayali Street and Hoyos Street, now called Paruro Street.

18 "There are more than 1,000 Asiatics, stuffed into tiny rooms without light or air; there they give themselves over to the vices inherent to their degenerate race. This is a scandal and one cannot comprehend how the municipality despite the repeated complaints of the press, allows the subsistence of such a foyer of infection and corruption" (Cisneros and Garcia 1898: 63). Hygienist J.A. Portella and polemicist S. Santisteban made the same criticisms.

19 During this period, the Chinese commercial companies financed not only the distribution of merchandise imported from Asia but also the export of new products such as sugar, cotton, and tobacco, which they obtained without going through intermediaries and thus made a profit from the haciendas which they rented in the province.
} 
Chinese,${ }^{20}$ the Government resorted to measures which aggravated the conditions especially of the working class and the small shopkeepers. A policy of urban expansion to relieve the congestion at the center of the capital was planned but unfortunately the projects launched by President Piérola to build quarters for workers on the periphery of the city were not successful except for the creation of La Victoria quarter. ${ }^{21}$

The year 1909 was the most tragic for the Chinese. On May 10, during the elections, parliamentary candidate, F. Cáceres, aroused members of the workers party by demanding lodgings for the workers and education for their children. Immediately a group of demonstrators paraded through the city. A large number went to the central market and began attacking the Chinese, shouting "Vive Piérola and Durand, death to the Chinese!"22 At the same time, public opinion pushed the government to denounce the 1874 Treaty of Friendship and Commerce with China. On May 11, while the Chinese government protested, the demolition of the Casa Lobatón had begun. The entire callejón Otayza was destroyed and hundreds of Chinese fled, seeking refuge in the houses of fellow Chinese. For the authorities and the inhabitants of Lima, this destructive act was a demonstration of rejection of the Chinese quarter and their desire to put a definitive end to immigration.

The overwhelming demand, backed by violence, was to stop the free entry of the Chinese and to put an end to the Treaty of Tientsin. In fact, the number of Chinese had been diminishing drastically in Lima itself, from 15,368 in 1876 to 5,049 in $1908 .{ }^{23}$ Following the upheaval, Ambassador Wu Tingfang $^{24}$ signed the Porras-Wu Tinfang Protocole which limited and regulated Chinese immigration. ${ }^{25}$ Despite such restrictions and attacks, the associations

\footnotetext{
20 See McKeown (2001).

${ }^{21}$ In this period a burgeoning industry was set up at the entrance of the Chinese quarter, in La Victoria quarter. As the factories and textile industries appeared, houses were built for workers. Some Chinese settled there to open small businesses and restaurants catering to these workers. Without being an extension of the Chinese quarter, this new workers' quarter where a number of mixed bloods lived played an important role. It had notably allowed the recently arrived Chinese to launch their small industries dealing in food and textiles (spinning mills), to increase the number of their warehouses and to find cheap lodgings. Despite the fact that the great majority of Chinese lived there, the Chinese quarter was still, in terms of property ownership, controlled by the religious orders, rich Creoles, Spaniards and Italians.

${ }^{22}$ El Comercio 10-5-1909. On this theme, see Muñoz (200: 169-70), and Rodriguez (1995: 397-429).

${ }^{23}$ Censo Nacional de 1876, Censo de la provincia de Lima de 1909. See tables in annex.

${ }^{24} \mathrm{Wu}$ Tingfang (1842-1922), distinguished jurist and politician, ambassador of Imperial China the United States, responsible for Chinese relations with Spain (Cuba) and Peru from 1896 to 1902 and from 1907 to 1909 . He defended the Chinese in these countries. Being a constitutionalist, he joined the Xinhai Revolution of Sun Yat-sen.

25 On this theme, see McKeown (1996).
} 
and guilds multiplied; thirty were registered in Lima in $1920 .{ }^{26}$ On the other hand, the great Chinese houses of commerce prospered and began to project another image to the population of Lima, that of an emancipated, modern China and a respectable Chinese community.

In 1918, the uprising of the Peruvian anarchist workers, some of whom had contributed to the founding in 1917 of the Anti-Asiatic League, ${ }^{27}$ again did not spare the Chinese from the central market. The lower classes of Lima were influenced by the workers' unions which rejected the Asians and their quarter. On the other hand, the intellectuals of Lima, although they supported the social movements, had a different perception of this quarter. Poets, high officials and philosophers found a charm there to which only they appeared susceptible. ${ }^{28}$ The poet Cesar Vallejo, the writer Abraham Valdelomar, and the political essayist José Carlos Mariategui would meet in the first chifa, ${ }^{29}$ the Ton Kin Sen, where the sampling of the most appreciated Cantonese cuisine, creole style, became part of the eating habit of the Peruvian middle classes. That was the paradox of a complicated and insatiable city: despite the increasing anti-Asiatic demonstrations, an infatuation had developed for the quarter whose exotic attraction was apparently only being discovered then.

It was also in this period that the illegal entry of immigrants began, particularly at the Ecuadorian frontier. Meanwhile the generation of Tusans $s^{30}$ succeeded their parents in running the business in the Chinese quarter. Despite the restrictions on immigration, between 1909 and 1930 more than 12,400 new Chinese entered Peru, fewer than five percent of whom were women. ${ }^{31}$ For the Chinese and the Tusans, the quarter was an ideal place to live where they found not only the imported products they desired but also new establishments such as schools and printing presses. The year 1931 saw the birth of a new magazine, Oriental (Dongfang Yuebao/Tonfu Yipo), intended for the Chinese and the Tusans with the double objective of firing Chinese national-

\footnotetext{
${ }_{26}$ Bilu zhonghua tonghui zongju yu bilu huaren (1886-1986), 217, Hong Kong.

${ }^{27}$ In particular, these were the bakery workers of the federation La Estrella del Perú, in direct competition with the Chinese and also the Japanese. They participated in this fresh outburst of anti-Asian racism.

${ }^{28}$ See Munoz (200: 155-81).

29 See Balbi (1999).

${ }^{30}$ On the theme of the generations of Tusans and their role in the recent evolution of the Chinese community, see Lausent-Herrera (2009a).

31 McKeown (200: 48-46). McKeown (1996: 63) gives the number of 22,993 entries between 1904 and 1937. The national census for 1940 indicated only 10,905 Chinese in Peru, 6,871 of whom were from the district of Lima.
} 
ism in the face of the Japanese invasion and educating the Tusans by promoting Chinese culture, which brought the term Barrio Chino into popular use..$^{32}$

After two decades of interrupted relations with the motherland, the number of "legitimate" Chinese, born in China, had diminished ${ }^{33}$ significantly and continued to decline. On the other hand, there was an increase in the number of Peruvian Chinese resulting from mixed marriages between the two ethnic groups or among the Tusans (the native-born), which added to the weight of this "illegitimate" creole part of its community. The increasingly noticeable presence of the Indian mixed bloods had begun to change the exterior of the quarter's streets though it had not yet modified its identity. The advertisements appearing in the Chinese newspapers of the 1970s give some ideas of the quarter's activities; they show the importance of the chifas Kong Ming, Tay San, Thon Po, and Chung Wa, in carrying on the traditional activities such as the fabrication and sale of shoes and furniture, while the activities of the great Chinese houses of commerce such as Pow Lung and the Pow Choc, which specialized in the import of crockery, were on the decline. One also notes the large number of Chinese funeral homes which were the first to disappear with the crisis of 1980-1990. At the same time advertisements reflected the modernization of businesses (the new market with eight floors was constructed in a modern style which contrasted with the old quarter). There was now diversification in the activities of the quarter with the appearance of travel agencies, a branch office of the "Nanyang Commercial Bank of Hong Kong," the importation of stationary and bureau supplies (Lau Chung) and the building of hotels. During this time the Chinese quarter was connected with the neighboring district of La Victoria which was the venue of activities such as the manufacture of noodles and sillao (soy sauce). The disappearing Chinese theaters were being replaced by the cinema which attracted the young. In 1971, the walls had posters of Sino-American productions (MGM) which were put up in the Apollo cinema (formerly a theater) showing enticing names such as Chang Cheuh's famous "One Armed Swordsman" produced by Runme Shaw.

\footnotetext{
${ }^{32}$ On the role of this magazine, see Lausent-Herrera (2009a).

33 According to the national censuses, there were no more than 5,932 Chinese in Peru in 1962 and only about 3,815 in 1971 . The Law of 1958 permitted the entry of 150 Chinese a year which did not lead to a revitalization of the Chinese community in Peru. See tables in the annex.
} 


\section{Great Changes: Political, Religious and Territorial, 1970-1985}

The years following the establishment of the military government in 1968 brought further depression in Chinese business in the quarter. The wealthiest businessmen fled to the United States and Canada out of fear of communism, leaving behind a politically and culturally disoriented population. Worse still, the government decreed the quarter unhealthy and ordered the numerous inhabitants to leave; those who remained out of an attachment to their temples, clubs and institutions had a hard life. The writer, Siu Kam Wen, a young man at that time, gave a very good description of this crisis which affected life in the quarter as much as its inhabitants who were shaken both by the new generation's loss of traditional values and by doubts about remaining attached to the Chinese quarter. ${ }^{34}$

The great import houses had been collapsing since the leftist military junta of General J. Velasco (1968-1975) came to power. The number of Chineseborn continued to decrease as members of the older generation passed on and there were fewer incoming migrants. Lodgings that were left vacant were taken up by the Peruvian mixed bloods and newcomers like the Lebanese. The young and the China-born Peruvians sought to leave the quarter, partly to mark their rising social status and partly to be near to their new ChinesePeruvian schools and the new clubs which had been moved outside the Chinese quarter to new residential areas such as San Borja. ${ }^{35}$ One must also see in this "internal migration" a rupture between the new Communist occupants of the Beneficencia China and the rest of the Chinese community. The departed representatives of the Guomindang had left behind the arch built at the entrance of the quarter as a mark of the Guomindang heritage, but that also plunged the quarters' occupants into a state of confusion as to their identity, now that another China was imposed upon them.

This young generation of Chinese-born and Tusan Peruvians was relatively well-integrated ${ }^{36}$ since they had benefited from a Catholic education run by the Jesuits, ${ }^{37}$ and were not satisfied after the war to search for a place in the community through the intervention of the review Oriental and its parochial

\footnotetext{
${ }^{34}$ See Siu (1985). When the book came out in 1985, Peruvian readers could for the first time penetrate this world which they had only seen from afar without understanding it. For the first time Lima's Chinese quarter was viewed with compassion but also from a critical perspective.

35 On the emergence of an Asiatic elite in Peru, see Lausent-Herrera (1996b).

36 On this theme, see B. Wong (1978).

37 The first schools in the Chinese quarter giving Catholic instructions were Chung Wha (1924) and San Min (1925).
} 
reunions. Because it was not possible for them to take up institutional community responsibilities, particularly as heads of these associations, this generation of Tusans, between the ages of 20 to 40 in the 1970s, responded to the call of the Franciscans who offered them the opportunity to form their own circles and networks if they left the Chinese quarter. This necessitated the relocation of the schools and the creation of new associations whose headquarters would no longer be in the Chinese quarter.

This separation which struck at the foundation of the education, religion and politics of the community, aimed in part to extract the converted Tusans and Chinese from the Chinese quarter, while promising them a Chinese language education, the continuation of Chinese customs, and the guarantee of their identity. It also aimed at undermining the secular and political influence of the Diez de Octubre school. In an indirect way, the action of the curacy which took place within a context of general and territorial weakening of the Chinese community of Peru - confirmed and reinforced the idea that social and economic promotion, also indicated by the level of education, implied a search for a new place of residence. Once detached from the Chinese quarter which in other ways was falling into ruin and no longer responding to the aspirations of the younger generations, the new types of associations all attached themselves to the action of the Franciscans ${ }^{38}$ and set themselves up outside the Chinese quarter. In this context of strong political tensions within the community, and an economic and political crisis linked to the take-over of the reformist military regime of General Velasco, the huiguans thus continued to lose their members and their influence and the Chinese quarter lost a part of its identity, as Wong (1978) noted judiciously on his arrival in Lima in 1971.

When Jau Kin Sui arrived in 1975 he was 25 years old and living in a modest apartment on Leticia Street near the Mesa Redonda at the edge of the Chinese quarter. As a newly arrived Chinese he was not disturbed by these changes. His only aim was to adapt himself to the changed circumstances as well as possible. The street merchants were then more and more numerous and although the quarter was impoverished, the huiguan continued to help the new arrivals like him. Jau was among the last arrivals who preceded the new Cantonese migratory renewal at the beginning of the 1980s. Because of

\footnotetext{
${ }^{38}$ It seems that the first association of Tusans, established in August 1961, was promoted by Monsignor H. Ferruccio who depended on it for the founding of the first secondary school in 1962 and then the great school Juan XXIII. The leading role in 1930-1960 of the review Oriental in bringing together an active body of Tusans was shared with the Catholic Church from the 1960s.
} 


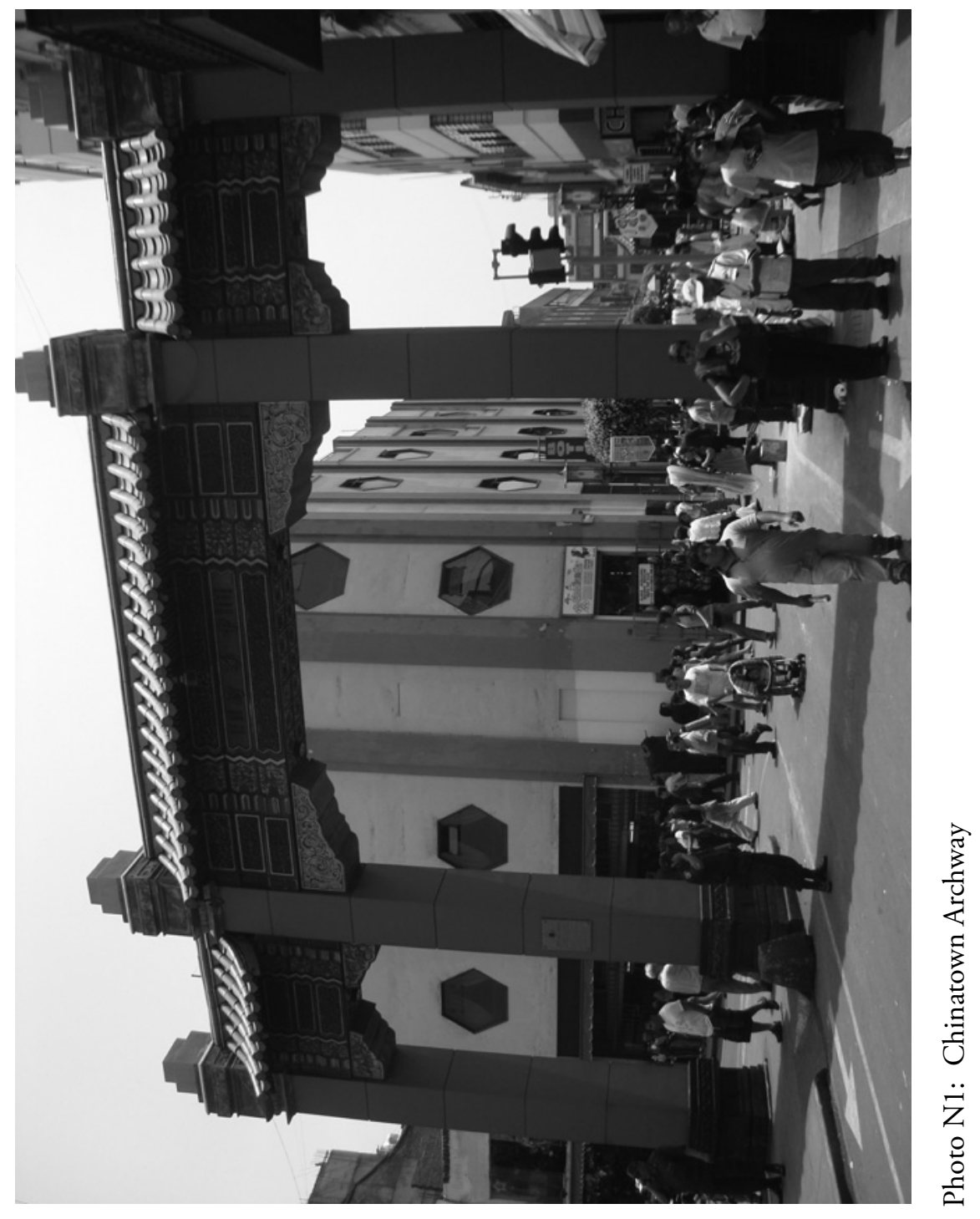


this, he had first to make his fortune in the Chinese quarter before he was able to leave his residence and join the Tusans who had already left in 1970. It was still a time when economic success took place first in the Chinese quarter with its strong networks; a change in residence was possible only after this. Despite being in an unfavorable environment, he found in the quarter the support necessary for him to succeed and he is now one of the three presidents of the Beneficencia and concurrently president of a regional association.

For reasons both internal and external, this period marks the end of homogeneity of the community, the programmed departure of the Tusans, the decline of solidarity, and the loss of their space which was eroded by other immigrants.

The Chinese quarter in the years 1980-1990 was not welcoming for the many immigrants who arrived during this period. The testimony of a number of young Cantonese women reveals their disappointment when confronted with the quarter's dirty condition, its lack of security and of economic activity. ${ }^{39}$ The entire town center was inffected by the same disease. Even the chifas, the Chinese-creole restaurants much appreciated by the Peruvians, no longer attracted clients.

In 1999 during the 150th anniversary of the introduction of the first coolies to Peru, a group of Tusan entrepreneurs led by Erasmo Wong, head of an enormous family enterprise, owner of the chain of supermarkets "E. Wong" and founder of the $\mathrm{APCH},{ }^{40}$ decided to give the quarter back its Chinese identity by relaunching its economic activity. Wong made an agreement with the municipality ${ }^{41}$ to begin revitalizing the famous Capón Street over a tenyear period, turning it into a pedestrian walkway and decorating it in Chinese style as well as revitalizing the activities of the chifas and galleries. This fairly positive undertaking, was carried out again in 2009, but it cannot be considered to be the origin of the renewal of the quarter or its economic upturn. The quarter's return to life is essentially due to the new migration, the dynamism of the new immigrants and the intensity of the commercial exchanges with China.

\footnotetext{
39 See Lausent-Herrera (2007).

40 APCH: Associación Peruana China, created in March 1999 with the aim "to promote, to publicize and preserve Chinese principles and customs."

${ }^{41}$ On this theme, see Lausent-Herrera, "El Barrio Chino de Lima: entre conservación del patrimonio histórico y recreación del espacio urbano," paper presented at the CEISAL IV Congress, June 30-July 3, 2010, Toulouse.
} 


\section{The New Immigration ${ }^{42}$ and Renewal of the Commercial Activities of the Chinese Quarter}

It was first the Cantonese, from the beginning of the 1980s — and even from 1975 but under other circumstances - who again blazed the immigration trail to Peru. Some Chinese and Chinese-born Peruvians reactivated the migratory network and arranged the entry of parents and cousins, often in the wider sense, into Peru to work in their restaurants in the Chinese quarter or in other quarters, workshops and factories for about two years, which was the time needed for the immigrant worker to pay back the costs of the trip and obtain the papers to stay in Peru, thanks to a very efficient system of corruption. These new Cantonese immigrants had only a vague idea of Peru and did not realize until their arrival in the Chinese quarter that they had been conned. Their disappointment was all the greater as the Chinese quarter appeared to them as dirty and dull with no hint of an El Dorado; and unless they were able to obtain help from their anxious family, the period of stagnation before finding work in Peru could turn out to be much longer than they had imagined. ${ }^{43}$ The time between arrival and the start of economic independence with the realization of a project - always of a commercial type took from two to four years. In the case of the Chinese quarter where restaurant employees, salesgirls and merchants selling imported products are found side by side, the means of integration and the chances of success differed and depended either on help received from the family or getting involved with the mafia network which could furnish papers, commercial premises and often capital.

The rundown lodgings held by some Chinese and Tusan families since the "ancient period," and the Chinese quarter and its institutions - particularly the Beneficiencia which sheltered more than one hundred lodgings - often offered the immigrants help in finding cheap or sometimes free housing. In 1991, the land registry of the Chinese quarter ${ }^{44}$ indicated a dozen buildings belonging to such families. The Chiong Chang, Lau Wong, Chi Terry Chiong, Yep, Chi Li Yong, Chang Yui ${ }^{45}$ families, also the Minzhidang Com-

42 The figures presented in this article are the results of a study using a sample of 235 Chinese visa seekers in 2002, their 148 guarantors residing in Peru as well as 171 visa holders in 2003. This study has been presented in part in Lausent-Herrera $2009 \mathrm{~b}$.

${ }^{43}$ On this theme see the statements gathered from the immigrants in Lausent-Hererra 2007 and $2009 \mathrm{~b}$.

${ }_{44}$ Reporte de predios y propietarios LC-14, Cercado, sector 06. Instituto Catastral de Lima. 23/04/1991.

45 These double-barreled family names show that they are either Tusans using, according to Spanish custom, the family name of the father followed by that of the mother, or naturalized Chinese obliged to use their two family names. 
pany and the Guomindang had welcomed a great number of the first arrivals. Little by little the outward appearance of the quarter began to change because of the visibility of the new immigrants (easily recognizable by their physical appearance, clothing and ignorance of Spanish), and the presence in the quarter's streets of women, children and old people, who had not been seen for a long time. This change was also noted by the media which regarded them with amusement, without really wanting to know the circumstances of their arrival. Their status, legal or illegal, is rarely mentioned since their presence has always been legitimate in the heart of the capital and in Peru in general.

It is only in the middle of the 1990s when several serious incidents resulting from the activities of the Chinese mafia broke out ${ }^{46}$ that the press discovered the ravages of the Dragón Rojo (Red Dragon). As the activities of this secret, criminal organization continued to cause serious concern, the community authorities drew up a petition addressed to both the Chinese Embassy and the Peruvian Ministry of the Interior in 2002, requesting the organizations be eradicated. But the problem was not solved, and the Dragón Rojo as well as other mafia networks ${ }^{47}$ caused enormously harm to the cohesion of the Chinese community and relations between the businesses of the quarter.

At the end of the 1980s and especially from 1991, immigrants from Fujian came in through a mafia network of traffickers. At the beginning, it was a question of finding a country of transit for the immigrants who wanted to go on to the United States or Canada. This period of transit can be of very short duration and in this case the immigrants, illegal and overstaying, were lodged either in the Chinese quarter or in the Chinese restaurants spread throughout the capital. The large numbers of these Fujianese, the high costs of their travel to the United States (from $\$ 45,000$ today), and the difficulties involved in the undertaking meant that many of them installed themselves in Peru temporarily thus contributing to the setting up of a new migratory chain. The

\footnotetext{
46 These included cases of companies held to ransom, kidnapping of adults and children, assassinations and above all possession of false passports and boats loaded with Chinese leaving for the United States. See Lausent-Herrera 2009b.

${ }^{47}$ The Peruvian police are only beginning to understand the operations of the Asiatic mafias which until this time were foreign to them. The Dragón Rojo recruits both the Cantonese and the Taiwanese and has been for several years involved in human trafficking, associating, it seems, with the Fujianese who have dominated the new immigration from the province of Fujian. The Mexican and Colombian drug cartels are now present in Peruvian territory; that of Mexico which is interested in the immigrant traffic to the United States, has had contacts with the snakeheads.
} 


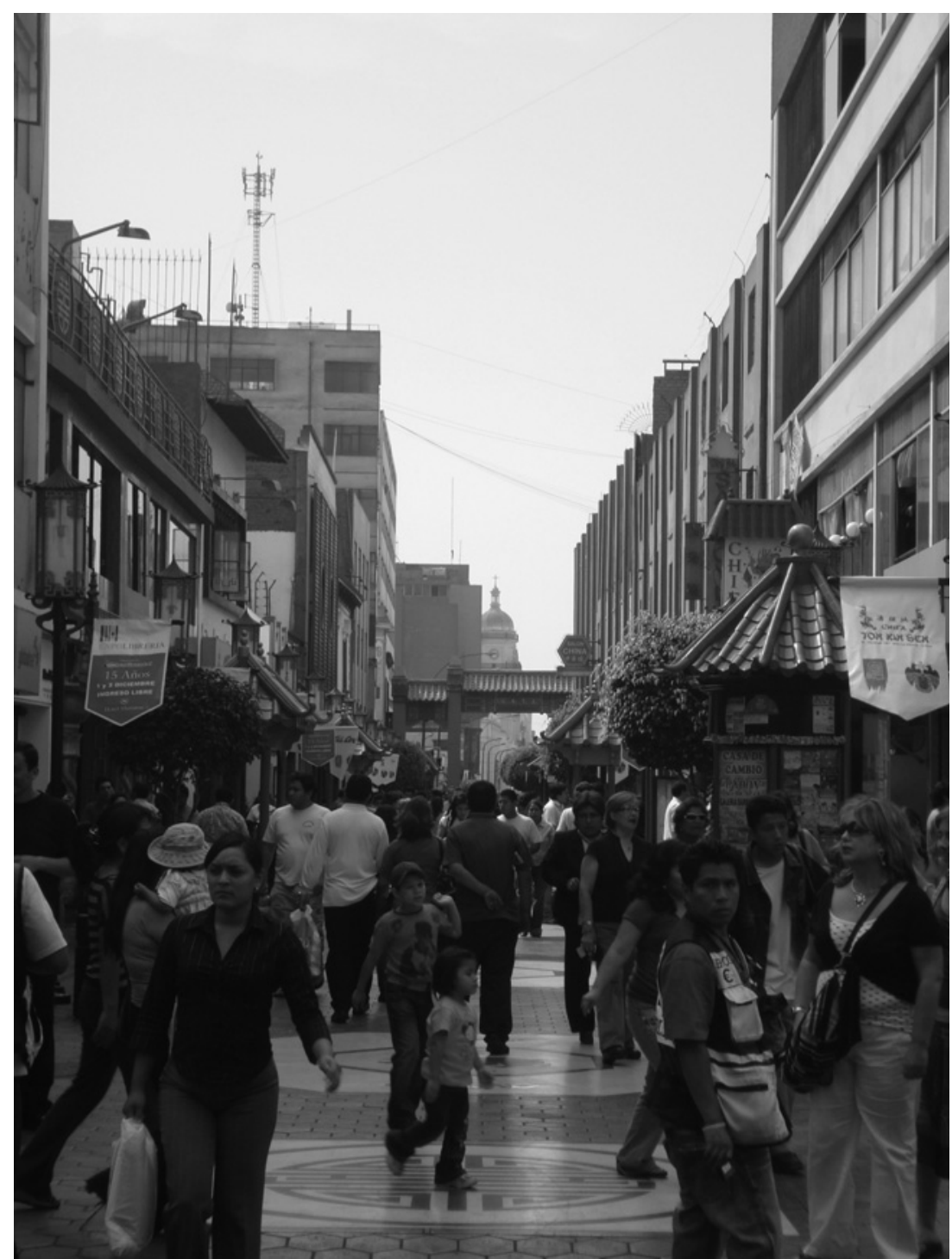

Photo N2A: Capon Street 
first arrivals came from the coastal regions of China ${ }^{48}$ and are engaged in new areas of activity, thus entering into competition with the older and newer Cantonese immigrants particularly within the Chinese quarter.

Informed observers and the Tusans themselves agree that the implications of this new immigration are enormous. In a certain way they fear that it is about to change their relations with China as well as the way the Peruvians see the Chinese community. Owing to the scale of the problem of illegal immigration over numerous years partly resulting from the active and efficient corruption of the immigration services, as much on the Chinese as on the Peruvian side, ${ }^{49}$ Official figures do not include this increase nor the ethnic and demographic changes which have taken place. ${ }^{50}$

In 1981 the census gave only the figure of 1,714 Chinese $^{51}$ living in Peru (1,237 men, 477 women). The China-born members of the Chinese community were at that time suffering from the non-replacement of their generations and the large numbers of Chinese leaving Peru. Twelve years later in 1993 their number grew to 3,728, a doubling of the population indicating especially an evolution of its composition with 2,307 men and 1,421 women. This increase, already underestimated because of the illegal character of this immigration, was due to the increased arrival of immigrants from Fujian, characterized by a rise in the immigration of women. ${ }^{52}$ Finally, the last census

${ }^{48}$ According to our information, besides Fuzhou, Quanzhou, and the Valley of Anxi on the southern border and Zhangzhou facing Xiamen, some come now from the mountainous counties of Sanming and above all from Nanping. Other accounts given by the Cantonese unused to being with the immigrants from Shantou - who belong to the dialect group of Chaozhou, and very close to the Minnan dialect of Fujian — regard these new immigrants as though they were Fujianese although they come from the eastern frontier of Guangdong. The second arrivals - if one agrees to consider them as Fujianese, as do the Cantonese installed in Peru come from Shantou. The latest arrivals, whom one hardly sees and who are constantly renewed, apparently come from the coast but above all from Anxi and Nanping.

${ }^{49}$ It's not my purpose in this article to illustrate all the undercurrents of immigration traffic and the price of Peruvian identity papers ( $\$ 3,000$ according to El Comercio of $21 / 8 / 2008$ ), but I cannot ignore the subject insofar as the figures produced by the censuses do not coincide with any other figures and do not correspond to the statements of the Chinese community.

${ }^{50}$ The case of the new wave of illegal Chinese immigrants in the Philippines described by Ang See is in many respects similar to that of recent Chinese immigration to Peru. In the Philippines, illegal immigrants take advantage of a weak and corrupt administration in order to import Chinese merchandise and obtain better places in the markets (Ang See 2007). The Philippines authority's reaction banning foreigners from the retail trade has no parallel in Peru, except for the fact that Chinese restaurant entrepreneurs have to hire Peruvian workers.

${ }^{51}$ Out of these 1,714 people, 1,191 were registered as nationals of the People's Republic of China and 523 were Taiwanese. 1,173 people were over 45 years old indicating a high rate of aging of the Chinese residents in Peru. See chart in annex.

${ }_{52}$ In the case of Peru, women are more numerous and for those who settle there, the level of education seems to be higher (Liang and Morooka 2004). 
of 2007 gives the figure of 3,450 Chinese residents in Peru, registering an increase in the arrival of women but a slight lowering of the number for men. This surprising figure which deserves closer analysis may be due to, among other explanations, a high rate of naturalizations between the two censuses. In 2004, while we were carrying out a study of the Chinese visa applicants at the DIGEMIN (Dirección General de la Immigración y Naturalización), we were given the number of naturalizations between 1990 and 2003 at our request. The result: 18,604 Chinese were naturalized during this period while before 1990 there were only 2,000 Chinese residents officially living in Peru. In the absence of new data on the naturalizations for 2003-2007 and considering the rapid acquisition of Peruvian nationality by the Chinese included those who never arrived in Peru, the naturalization factor may in part explain a figure so far removed from reality. But the problem persists because there are no traces of these immigrants entering the country. The discrepancy between the numbers of Chinese accounted for in the Population Census and that of the number of Chinese that acquired the Peruvian nationality may be partly explained by the fact that during Fujimori's presidency, an undetermined number of Chinese bought the Peruvian passport (the decree $n^{\circ} 663$ promulgated in 1992).

The work that has been carried out using the files of visa applicants and of the Chinese residents, naturalized Chinese and the Tusans who are guarantors $^{53}$ of the immigrants and who had brought them over, has allowed us, in the absence of other available sources, to draw up information from the files concerning a total of 383 persons (first semester of 2002) and 171 persons (August 2003) providing a profile of the present immigrants. In 2002, 40.8 percent of the visa applicants were from Guangdong and 24 percent from Fujian. One notes a variation in the places of origin, especially with the more numerous arrivals of people from the district of Baiyun (Renhe) north of Guangzhou and the district of Dongguan. The remainder of the visa applicants, made up of government employees and small businessmen attached to Chinese commercial houses, came generally from the central provinces (Hebei, Hunan), and the north of China (Beijing, Tianjin) and Dongbei with the arrival of small businessmen from the province of Liaoning. Although this is an extremely interesting phenomenon, reflecting the economic ambitions of the Chinese in Peru and Latin America, we will not study the case of those immigrants who do not live or who have never lived

53 It seems that $77 \%$ of the guarantors in the 2002 study arrived between 1997 and 2000 . This indicates the appearance of a new and very active migratory chain. $60 \%$ of the guarantors are restaurant workers, restaurant owners and management personnel, $26 \%$ are small businessmen. See Lausent-Herrera, 2009b: 84-89. 
in the Chinese quarter, even if some of them among the merchants have relations with the new arrivals. This group of people are generally given accommodation in the great houses of commerce or are grouped together in apartments in the (upper middle class) residential quarters of Surco, San Isidro and La Molina. ${ }^{54}$

In the 2003, from the sample of Chinese holding a resident visa, the Cantonese represented only 36 percent while the people originating in Fujian were 40 percent. These figures are the only ones which give, for the moment, proof of the inversion of the relations between the Cantonese and the Fujianese within the community especially in the commercial activities shared by both dialectical groups in the interior of the Chinese quarter. Also in this profile, 35 percent of the immigrants were women, mostly single or divorced (57.1 percent) with a median age of 29 , while that of the men was 36 and 59.5 percent of the immigrants requested a tourist visa while 35 percent wanted a business visa. ${ }^{55}$

Until the 2000s the Chinese quarter sheltered and provided work for the majority of the new immigrants whether they were from Fujian or Guangdong. As soon as the illegal immigrants were brought in by the restaurants networks (chifas) they were dispersed to establishments outside the quarter. Those who actually lived or worked there were mostly those who had chosen to live in Peru.

\section{Renewal of Commercial Activities in the Chinese Quarter}

As we have seen, the Chinese quarter is a space with movable, elastic frontiers depending on whether one sees it from the point of view of the consumers who know only Capón and Paruro streets, or that of the merchants whose view includes ten more blocks, or that of the commissioners of the Institute of Culture (INC) which skips certain blocks, or finally from that of the municipal authorities which include others (the "zone of influence"). For our

\footnotetext{
54 In 1992 Peru sold its only steel manufacturing complex located at Marcona (Nazca district) $500 \mathrm{~km}$ to the south of the capital to the Chinese company, Shougang. Since1993 this company has brought most of its qualified workers and executives from China. During their holidays the latter come to the Chinese quarter and lodgings are reserved for them in the district of San Isidro headquarters of the company. Other Chinese companies also provide company housing and cooks at their service.

55 The business visa was issued in 2002 subject to a $\$ 10,000$ deposit. There have also been visas for investors issued for a $\$ 25,000$ deposit since 2001 (it was $\$ 20,000$ in 1992 when it was created under the presidency of A. Fujimori).
} 
study based on the National Economic Census of 2008 microdata $^{56}$ we have looked at eleven streets, which form seventeen blocks. They consist of three long arteries running from the Rímac River in the north to the southern limit of Historical Lima (Ayacucho, Andahuaylas and Paruro Streets) and the streets traversing them, the most important of which are Huallaga, UcayaliCapón and Miró Quesada Streets. In the center of this ensemble, at the level of blocks 5, 6, 7 and 8 is the central market (Mercado de la Concepción) surrounded by Huallaga Street (1,553 stores), Ayacucho Street (1,414 stores) Ucayali-Capón (497 stores) and Andahuaylas (1,767 stores) (See Map n $\left.{ }^{\circ} 1\right)$.

The center of Lima contains a total of 45,164 commercial establishments; the seventeen blocks which are relevant to this study include the "zone of influence" which alone represents 11,369 commercial premises. The locations of stores for sale vary from a $4 \mathrm{~m}^{2}$ space often in a commercial gallery occupied by the smallest retailers, to the big establishments of more than $100 \mathrm{~m}^{2}$. The great commercial density is explained by the presence of numerous galleries with several floors and commercial buildings with many entrances, built since the 1970s on the spot of the old run-down building acquired by the real estate companies whose stockholders were often Tusan (Lau-Kong, Ch. Wu, Jui Lin, Chy, Tay). These galleries hold several thousands of premises parts of which - because of poor management - are not always occupied or are used as storage space for merchandise bought in bulk from Chinese or Tusans in the quarter or as annexes for the large importing companies. Tiny boutiques when well located, are worth a great deal. A space of $4 \mathrm{~m}^{2}$ in the Galeria Barrio Chino on famous Capón Street was worth $\$ 50,000$ in early 2010; in this same gallery another $4 \mathrm{~m}^{2}$ space was rented for $\$ 100$ a month.

The galleries often follow the example of the blocks of streets where they are located and specialize in the sale of specific products. In Andahuaylas street, the street with the most gallery entrances, the Imperio Gallery is crammed with stationery, printing presses, draper's shops, embroidery ateliers, toys and gift bazaars etc. The majority of the products sold there are imported from China. In the El Dorado gallery one can find everything for decorating children's parties and gifts for birthdays. These boutiques are often run by Tusan women who still live in blocks 11 and 12 of Huanta Street and Paruro Street at the edge of the Chinese quarter. In the Mina de Oro gallery are all the costume jewellery and fashion accessories are from China, stocked

${ }^{56}$ Censo Nacional Economico de 2008. INEI. We have also worked with individual records from the RENIEC (Registro Nacional de Identidad y estado Civil), the SUNAT (Super Intendencia Nacional de Administracion Tributaria and its Registro Unico de Contribuyentes) as well as information sites concerning the enterprises: www.UniversidadPeru.com//empresas and Creditos.Peru.com. 


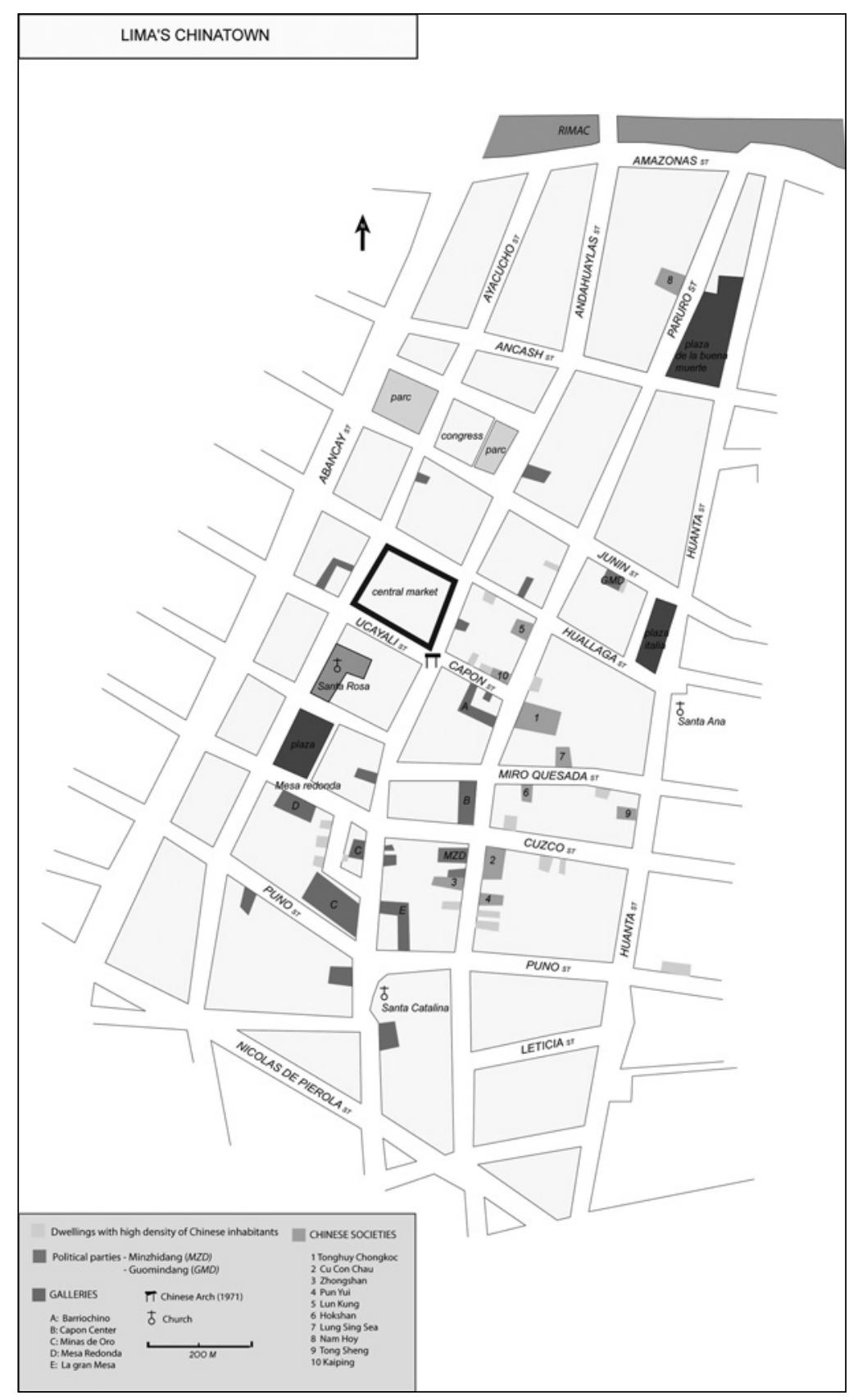

Map 1 
and sold by the Peruvian retailers. In the Capón Center on Paruro Street, the stores stock up on medical and beauty products. These products, also from China, are often confiscated by the health authorities. There are more than fifteen galleries within this perimeter. Their poor maintenance, the crowds, and the dangerous products they contain such as fireworks imported from China before the Christmas celebrations have caused several terrible fires, one of which at the Mesa Redonda in Cuzco Street took more than 400 lives at the end of December 2003. In a study of the consumers of the Chinese quarter, we asked if some places on the outskirts or which are not typically Chinese could be considered as being a part of the Chinese quarter. According to certain studies, Mesa Redonda, too modern and mostly frequented by Peruvian sellers and buyers, does not belong to the Chinese quarter. But for others, Mesa Redonda is an integral part of the quarter for two reasons. The first is that many immigrants including Tusans and Chinese doctors, used to lodge or are still lodged around Mesa Redonda. The second is that Mesa Redonda and the conglomerate of galleries around Leticia Street exist only because of the multitude of Chinese merchandise sold there, imported especially by the recently arrived Chinese, mostly Fujianese. For the Peruvians from other quarters, to go to Mesa Redonda is to go to the Chinese Quarter. One sees again in this particular case the elasticity of the definition and the limits of this quarter and its zone of influence.

Identifying blocks Five to Eight of Paruro Street and the street which crosses it, Ucayali-Capón, presents no problem. They represent the heart of the Chinese quarter. On the one hand the urban development of the $\mathrm{APCH}$ has reinforced its Chinese character, and on the other, these two streets have the highest concentration of people (merchants, employees, residents) of Chinese origin. It is also in Paruro and its side streets (Junín and Miró Quesada) that the offices of the associations are located: the Tonghuy Chonkoc, called Beneficencia China, the huiguans $\mathrm{Cu}$ Con Chau, Zhongshan, Pun Yui, Lungkung, Hokshan and the Lung Sing Sea, the Minzhidang and the Guomindang (with their respective printing presses). Only a little outside is the Namhoy in block Three of Paruro, and the Tongsheng (Tung Sing) and its Taoist temple in block Nine of Huanta. On this subject it is interesting to note that recently, despite the difficulty in finding premises in this axis a new association linked to the renewal of Cantonese immigration, the Kaiping (Hoiping) society, is installed at the junction of Paruro and Capón. The Tusan Association of Callao, the port of Lima, is also established there.

Until five years ago, one would have doubted the vitality and the durability of these associations in the Chinese quarter for several reasons. First, there was the issue of aging of its members and the tenuous affiliation of the new immigrants who turned more willingly to the Beneficencia China. Second, 
the costs of real estate which had long made certain association directors believe that it was better to sell, leave the quarter and buy a new premise in the residential quarter of San Borja where many of them lived. But prices in San Borja also went up just as quickly as those in the Chinese quarter which made such real estate transactions impossible. The Pun Yui huiguan thus decided to abandon this project and instead invest in repairing and modernizing its premises. The Zhongshan huiguan which had rented its offices to storekeepers had no real offices for the association itself and this distressed its members particularly as they had nowhere to hold funeral ceremonies. More than premises for the associations, Paruro and Ucayali-Capón Street have the greatest density of boutiques, restaurants (the famous chifas) and bank branches. ${ }^{57}$ The latter are run by the Tusans and their employees speak Chinese. The transfer of money between China and Peru is the main activity along with deposits and loans linked to import/export activities. Feng Shui businesses and Chinese imports of clothing and fashion accessories which first appeared fifteen years ago have led to the disappearance of one of the most flourishing businesses of this street: that of the fabrication and sale of furniture by the Chinese and Tusans of the older generations. These two streets are the beehives where Peruvian buyers, Tusans and Chinese visit the galleries and patronize the best restaurants (Wa Lok, Salón Capón, Salón de la Felicidad, Salon China, San Joy Lau), Chinese pastry shops and the small casinos of Capón (Tragamonedas). Meanwhile the new immigrants have transformed the floors meant for lodgings into offices for dentists, doctors, acupuncturists, accountants, translators, hairdressers and even shamans. One observes that this new occupation of the space follows a new partition between Cantonese and Fujianese. As such an entire building next to the Beneficencia China belonging to the Charitable Society of the City of Lima has been totally taken over by recent immigrants from Fujian.

An examination of the 2008 economic census in connection with the available information on the enterprises in the SUNAT registers reveals two important moments in the spatial and commercial reconquest of the quarter. The first came after the Fujishock ${ }^{58}$ when improvement in the economy began feebly to take effect. New businesses appeared from 1992 and increased little by little until 1999 . The new immigrants played a part but at that time

\footnotetext{
57 In Capon Street, Banco Continental, Scotiabank, Banco Financiero, Banco Interamericano de Finanzas, Interbank; in Paruro Street, the BCP, CrediScotia, Banco Continental and Western Union. These banks employ young Chinese-born Peruvians speaking Chinese and having lived in China.

58 The Fujishock (11 August 1990): aftermath of the measures called for by the FMI to end the inflation and relaunch the Peruvian economy.
} 
it was the Tusans and some naturalized Chinese who reinvested in the quarter. The second moment began with the year 2000 but it was between 2004 and 2008 with a peak in 2006 that the number of creations of enterprises was the highest. Between the two periods a reversal took place: now it was the new immigrants/residents and the recently naturalized who invested and opened up new businesses. In Ucayali Street there were fifteen businesses, in Paruro Street — the most "Chinese" Street after Capón-Ucayali — one can count 22 more, and nine others in Andahuaylas street. That is, 46 enterprises were newly set up excluding the numerous others which were their branches and mini-warehouses dispersed throughout the quarter, and also not counting those they inherited or those in which they were associated with Tusans. Thus, the Tusans who had been very visible in these three streets were supplanted even in Andahuaylas where they nevertheless took up again a few activities (opening five stores) despite the competition during this period. This increase in business run by the new immigrants shows that they were able to rent and buy the spots formerly occupied by the Tusans in the blocks on the most desirable streets. In compensation, this renewal of activity was accompanied by a sharp rise in the number of jobs ${ }^{59}$ taken by the Peruvians (since selling demand a good level of Spanish) as well as many from the reservoir of new immigrants of whom a majority came from Fujian, who arrived in great numbers during this same period. The period 2005-2010 also saw the abolition of certain taxes on imported Chinese products due to the conclusion of Treaty for Free Commerce between China and Peru at the beginning of 2010, which boosted the import of all sorts of products from China with a tendency, as will be seen, toward specialization.

\section{Old and New Activities: Competition}

Following the practice of the great 19th-century commercial houses like Wing On Chong (Namhoi) and Pow On (owned by Hakka from Taishan and Zhongshan), which recruited their associates and employees from their counties of origin who speak the same dialect, the small commercial companies in the Chinese quarter were set up in the model of the family enterprise, i.e. the Cantonese model. This model is visible in some of the businesses which still exist, not only always in the hands of the same family but always in the same economic sector. Thus the Sen, the Chu, and the Siu have been

59 Because of the uncertain declarations by the storekeepers to the Senate during the 2008 economic census of the number of employees, our figures are underestimated: 350 people in Ucayali Street, 300 people in Paruro and 150 in Andahuaylas. 
in the bazaars for several generations. These businesses in the Chinese quarter have for a long time remained faithful to certain activities of traditional business such as the restaurants and the sale of food and condiments necessary for the preparation of Chinese dishes. The Cantonese who arrived in the1980s and 1990s with the first wave of immigrants took up the businesses freed up during the crisis and began to diversify their activities, as much for reasons of demand as, a little later, for reasons of competition. This is because in between times the Fujianese immigrants had begun to set themselves up in business and get into everything - especially in the import sector - and introduced new products onto the market. They also profited from the mafia networks which had brought them along. Thanks to their contacts in China, they have been able to get the best prices and to sell the same products cheaper than their Cantonese neighbors. Distrust between Cantonese and Fujianese has deepened resulting from this unfriendly competition. This is perpetuated in the new activities as the Cantonese and Fujianese compete in getting control of the most lucrative activities besides the restaurant and the import businesses.

In the past shoppers went to the Chinese quarter to buy crockery and electrical appliances at the hardware store, to have invitation cards printed for a marriage or a children's fete, and to buy piñatas, presents, bibelots, plastic basins and retail or wholesale stationery. These activities are still there but the neighborhood has changed with the onset of globalization. ${ }^{60}$

Hardware stores used to sell few imported products before; this is no longer the case. In the 1990s, the Cantonese took over the hardware stores and began importing from China a number of products, hence the creation of AJC-import-export. In 2000, the Sun West International Company was set up by the Fujianese. This enterprise which brought over from Zhongshan and the industrial park of Ningpo items such as neon lights, spare parts, electric material and all sorts of tools was also capable, if one can believe it, of making an order of $\$ 150,000$ in 2008 for meat choppers, Frigidaire motors, rechargeable batteries, electronic scales and exhaust pipes. Another enterprise, Importaciones Megalo, was created in 2005 and run by a Fujian immigrant. It takes orders for heavy material but sells above all fluorescent tubes and lamps in the quarter. Thus while the Cantonese immigrants group together leaving the model of the family enterprise, the competition among Fujianese immigrants is starting in its turn.

${ }^{60}$ Ceccagno analyses how the recent Chinese immigrants have taken advantage of the globalization to change their economic activities from working in an isolated garment and leather niche to large scale transnational entrepreneurship importing and selling competitive manufactured goods from China (Ceccagno 2007). 
The famous bazaars which have made the fortune of many Chinese have also evolved. They sell reasonable quantities of bibelots (knick-knacks) and inexpensive decorative objects: buddha, guanyin and other divinities bought by the Peruvians, and objects of faience of indeterminate style: clocks, tea services and Chinese lanterns. These ornaments are still popular among the ordinary people and continue to be imported but in much greater quantities with new models made in China. New businesses have thus been opened by the Fujianese immigrants, such as Bao Long Commercial, but the merchandise is no longer sold in the Cantonese mode, i.e. in the big stores. They are now sold in hundreds of small boutiques scattered in the quarter's galleries.

In the past the products sold in the Chinese bazaars were objects made of plastic for everyday use like basins, plates, etc. These products from another epoch have diversified and adapted. Small Chinese and Tusan industrial entrepreneurs have been interested in them for a long time; the Kong family, then the Tusan family, Yi Choy, ${ }^{61}$ have become producers. Since 1992 the products with the brand Superplast which has its headquarters in the Chinese quarter, are sold by the Tusans in several galleries in the quarter. In 2005, the Terra Plastic brand increased its sales. This sector, in which Yi Choy controls the manufacture, has entered into competition with the Chinese imports on sale at Heng Lung since the year 2000 and as such Peruvian plastics may no longer be sold in the Chinese quarter.

Another sector held for some time by the Chinese is the import of paper products such as school and office supplies. Initially in the hands of the Lau Kong family, the brand Lau Chun was for a long time the leader in this line. Then other family enterprises took over the market. The Tusan family Chiang Leung, who had founded the Tai Heng Co. in 1979, enlarged the market by also importing computers; the Koc family founded in its turn the brand Tay Loy SA. These businesses started in the Chinese quarter, spread to other districts of Lima and now are also in business in the large provincial cities. The two families have more than thirty branch offices each and do not seem worried by an incursion of the new immigrants into their sector of activity.

\section{Chinese Restaurants in the Heart of the Barrio Chino}

Catering in the Chinese quarter remains a traditional activity which is at the same time the most stable; it is however also the most fluctuating. Even if the location and sometimes the shop signs remain the same, the owners may not

${ }^{61}$ The Yi Choy belongs to a very old Hakka family from Di Hai (Toishan) which has dominated the fabrication of shoes and the industry. 


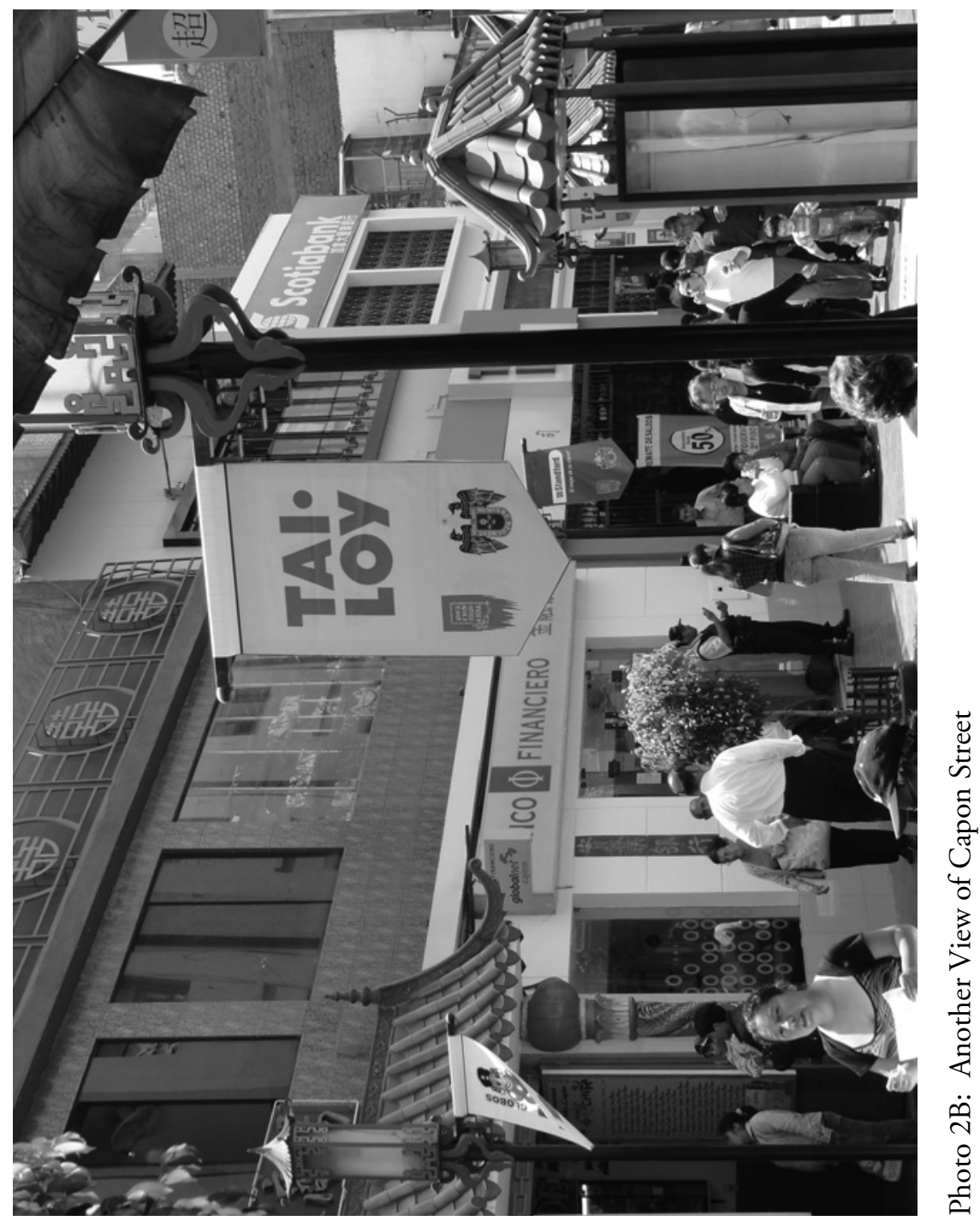


last very long because competition here is extremely fierce. Along with the paper business the restaurant business has also created the most jobs (more than 200 for Tai Heng alone in the Chinese quarter). This sector which in the past was reduced to chifas and some street vendors has greatly diversified in and outside the quarter. Their establishments vary in size from the oneperson enterprise to the gastronomic restaurant of more than 100 places for the diners passing by the little ten-place restaurants. One can count more than 35 restaurants between block Six of Ucayali Street and Capón and Paruro Streets. The importers, wholesalers and manufacturers of Chinese foodstuff belong to this sector too and are also big employers. The restaurant-patisserie Fung Yen employs a total of 55 people in its two stores; the Capón salon owned by new Cantonese residents opened in 2001 and employs sixty on its staff.

In the past restaurants were uniquely Cantonese but the Fujianese have begun to take over this very profitable sector. Those Fujianese and Cantonese who are in the same networks of illegal immigration have opened in the emergent popular urbanizations (conos) and other districts of Lima a large number of Chinese restaurants (chifas) of all kinds including those specializing in regional cuisines, little places where they sell take-out food ("chifas al paso") and offer dishes currently available in the mostly working class districts, such as caldo de gallina, ${ }^{62}$ and rotisseries which the Tusans started in the 1950s but which the new Chinese residents are also trying to take over. ${ }^{63}$ There are also the Chinese fastfood outlets introduced into the Chinese quarter in 1979 by a Tusan family, the gastronomic restaurants associated with the hotels and casinos and wealthy quarters such as San Borja, Surco.

There remain a few chifas in the Chinese quarter belonging to the Tusans, like the San Joy Lao, a 1930s-type restaurant in Capón Street which has been saved by a member of the APCh. The majority were taken over or set up in the 1990s like the Hong San (1993) by the recently arrived members of the Siu family ${ }^{64}$ one of whose members is connected to the management of the Beneficencia China. There are members of this family who also work in Paruro

${ }^{62}$ A place serving only chicken bouillon and giblets. These businesses destined for the working class (taxi drivers particularly) are very profitable and not very demanding to run.

${ }_{63}$ The case of the rotisseries is very interesting because they were very quickly taken up (after 1950) by the Chinese and the Tusans. It is not rare to find in Lima and in the province chifas which are also rotisseries. But what distinguishes them is the marinating of the chickens before roasting. One family, the Wongs, has had international success with their "Chicken Pardo" which is sold in New York on 7th Avenue and in some other Latin American capitals. In 1997 a Chinese resident opened a competitive brand "Qué Rico" in Ucayali Street which now has branches in other districts of Lima.

${ }^{64}$ Since the 19th century, Luo and Siu have been very active in every aspect of catering. After an interruption, new members arrived in the Chinese quarter at the beginning of the 1990s. 
Street in the Salón de la Felicidad. The Salón Capón in Paruro Street, a restaurant in great demand owned by new Cantonese residents since 2000, had to be handed over in 2008 due to, according to some sources, a gambling debt owed to residents from Fujian, resulting in the restaurant losing a portion of its customers to the Salón de la Felicidad. One of the great successes of Paruro Street is also that of Wa Lok. A. Chang, a young Cantonese, opened the first restaurant in 1997 which was followed by a second and a third. Chang took as manager a young Tusan woman, L. Com, a distant relation who besides bringing over very good Cantonese cooks also took care of his clientele of government officials, university intellectuals and artists, introducing them to Chinese cuisines and campaigning to improve the standing of Chinese creole cuisine and the Chinese quarter through holding contests in drawing, composition of poems, etc.). Under L. Com, Wa Lok became an established restaurant. Benefiting from the good will of the media, the owner opened in Miraflores a new and imposing Wa Lok and then another hotel-restaurant-casino in the newly fashionable district of San Borja, following a migratory movement out of the Chinese quarter begun by the immigrants from Fujian. Until then the chifas of the Chinese quarter had never been moved to other districts; they have thus entered into competition with the older and newer chefs already working in the districts far from the city center.

There are other activities linked to the chifas such as the manufacture of pasta and raviolis. In the past these small scale industries were numerous in the quarter especially in the district next to La Victoria. Because of sanitation-related issues (health checks in the quarter have become frequent) and the lack of space, these mini industries have disappeared from the quarter. One small enterprise, the Wah Fung Peru, has remained in Ayacucho Street manufacturing Chinese noodles. Some other small places have also appeared (like the ravioli apartments in France) where wantan and other stuffed breads, mimbao (mianbao), are made and sold in the streets. In a very old courtyard in Capón Street, in the middle of some small 1930s buildings where a large number of newly arrived Chinese live, one can also find Chinese vegetables, fish and crustaceans bought by the Chinese but sold by the Peruvians. Pigeons and zongzi (tamales chinos) are sold by Chinese women who have recently arrived. In the back of the courtyard one can find the famous raviolis (zhenwei) made by Fujianese immigrants and a few Peruvian employees.

In the face of this traditional form of Chinese catering and fierce competition, other related activities have also emerged ${ }^{65}$ A naturalized Chinese who

\footnotetext{
65 Another new development linked to the expansion of the restaurants has been the appearance of Chinese accounting offices for restaurants and import businesses which also play at times the role of brokers.
} 
is the owner of the Kong Wa restaurant in Andahuaylas Street has diversified his activities by opening his own chain of rotisseries, Villa Chicken, outside the Chinese quarter. Remarkably he has also created a new service agency: the MOL Invert, a kind of labor exchange to help the chifas in their search for personnel. The agency is also able to help a restaurant to start from scratch, whether a chifa, pizzeria or rotisserie. Because the new immigrants were faced with the beginning of saturation of Chinese-Creole restaurants in the middle class areas, more and more of them are opening restaurants outside the Chinese quarter which are not Chinese or Peruvians. The success resulting from this initiative may be measured by the number of jobs created in the Chinese quarter: they went from 14 in 1997 to 91 in 2010. ${ }^{66}$ Always with the aim of satisfying the craze of the Peruvians for Chinese cuisine and their desire to procure the utensils for the Asiatic cuisine: woks, knives, choppers, etc., new specialized import houses have been opened. For example, Zhou Ya became in 2008 the importer of light and heavy kitchen equipments such as restaurant stoves and tables with lazy susans, chairs, etc.

\section{High Stakes for the Distribution of Chinese Food Products}

The importers of Chinese food products and condiments, as we have seen, are concerned with the success of the chifas. In the past, the former great import houses also attended to, among other activities, the arrival of canned goods, condiments, and dehydrated products indispensable for the preparation of Chinese dishes in the restaurants and in Sino-Peruvian homes. Despite the uncertainties - the closing off of China and the strict import restrictions imposed by the military government - they ensured that supplies get to the Chinese quarter and the whole of the country (Chinese from other provinces come to Lima to buy their ingredients). ${ }^{67}$ With the disappearance in 1970 of Wing On Chong, and the beginning of the first supermarkets in the higher middle class districts at the end of the 1990s, new businesses specialized in selling grocery products and canned food, not only Asiatic but also Peruvian, thus continuing the vocation of the old Chinese establishments of the quarter, opening to Peruvians as well as to Chinese. The

${ }^{66}$ Censo Nacional Económico, 2008. INEI (microdata), SUNAT, 2010 and other years.

67 Except for the Chinese in the Amazonian port of Iquitos which is somewhat isolated from Lima's Chinatown thus incurring high transportation costs. Between 1880 and 1930 they got their supplies directly from Hong Kong thanks to ships linking Brazil, England and Hong Kong. 
person who made the transition between the disappearance of the Wing On Chong and the return of the shops specializing in Chinese food products is S.J-K. Arriving as a young man in 1975, he became a wholesale importer and together with his wife who is Tusan, and other stockholders, opened in 1991 the first import company in Paruro Street, S.B. Trading. This was followed in 1996 by a restaurant and finally in 2005, the first mini-market "Hong Kong" where one can find all the products required for the Chinese cuisine: crockery, alcohols and Chinese decorations. Since then he has opened two other supermarkets in San Borja and Callao. He has diversified his activity and is looking for a new market catering to Peruvians and Peruvian-Chinese in Canada. ${ }^{68}$ Also opened during the same year was the Kenex Corporation, a Tusan family enterprise, which brought over from Shanghai, Thailand and Vietnam medicines, liqueurs, and dried shrimps. Hong Kong Market was the first to conclude exclusive commercial agreements on certain Chinese products, and those who followed its example would do the same with competing brands.

The strategic location of S.B. Trading and Hong Kong Market allowed both companies to employ close to fifty workers. Besides the places for business, the enterprise disposed ${ }^{69}$ of more than five warehouses in the quarter and acquired five others outside it. Generally the Cantonese businessmen and among them, some important members, were not aware of the keen competition resulting from the arrival in the Chinese quarter of the new Fujianese immigrants, in particular the recent opening by the president of the Fujian Society of another mini-market facing a Hong Kong market. Actually, whether they are Cantonese (in the minority) or originating in Fujian, the competitors are numerous operating between Paruro and Ucayali Streets. They are all searching, besides the ideal location - a theme which will be touched on later - for a captive clientele, thanks to the famous contracts regarding the representation and exclusive sales of certain Chinese brands. It is important, when supplying the restaurants, to be the only authorized distributor to sell certain sauces or canned mushrooms in Peru. Whether it be the China Commercial Central Co., an import-export business opened in 2002 by the new immigrants, or the Kenex Corporation, each holds its own import brands: Chaokho for canned fruit and vegetables and White Rabbit for candy. But if some Cantonese immigrants were able to make their fortune

\footnotetext{
${ }^{68}$ Among other things, l'Inca cola, symbolic drink of the Peruvian Chifas, quince cake (Kingkong), pannetones, chocotejas (delicacy made with milk, sugar and chocolate) and vegetable oil "sacha Inti" from Amazonia.

${ }^{69}$ Censo Nacional Económico, 2008. INEI (microdata). SUNAT, 2010 and other years.
} 
in this sector between 1980 and 2000, greater fortunes are still being made in the Chinese quarter. For in the Chinese quarter, the supermarket is not king. At present the new hyper specialized companies such as Tay Feng Co. with a small number of employees are the ones that rule the market by importing in one blow four tons of dehydrated mushrooms in 2007.

The importers of Chinese food products have therefore multiplied because the number of restaurants has increased, but so too have the Chinese and even Peruvian consumers. The return of these new businesses which survived with difficulty during the long crisis of imports (from 1971 to 1992) was at the beginning taken as an incentive by the Cantonese, more at ease in this quarter because of the network which has always supported them. In reality and over time, the Cantonese have lost ground. It is the Fujianese immigrants, the origins of whose investments are often doubtful ${ }^{70}$ (though this is also true to a lesser extent for certain Cantonese), who are now about to take over. Nearly fifteen years have gone by since the arrival of the first entrepreneurs and investors from Fujian. Since the start of the immigration chain their presence in the Chinese quarter has been reinforced and their business has been doing well.

\section{Knickknacks, Toys and Cigarettes in the Chinese Quarter}

The traditional sectors of transformation such as catering and the imports linked to it, developed in the competition within the Chinese quarter. The introduction of new import products of mass marketing targeting mainly women is essentially the work of the last wave of immigrants and if one speaks of globalization, these products are an illustration of it. They are the same costume jewellery, cosmetics and fashion items that one can buy at modest prices in Paris, New York or Lima. The bijuteria where costume jewellery and articles of fashion are on sale is a new sector entirely dealing in Chinese imports.

The first to import toys from China in the 1970s were the Tusans, such as Tai Heng Co. As a wholesaler, it distributed a part of its products not only to the small Peruvian retailers of the quarter but also to the Chinese boutiques in other districts of Lima and even the provinces. Later this role diminished with the appearance of the great supermarkets and the big department stores. In 2006, 80 percent of the toys sold in Peru were Chinese made ranging from

${ }^{70}$ According to the SUNAT, Ting Long for example opened in 2005 with an imported stock valued at 2 million dollars. 


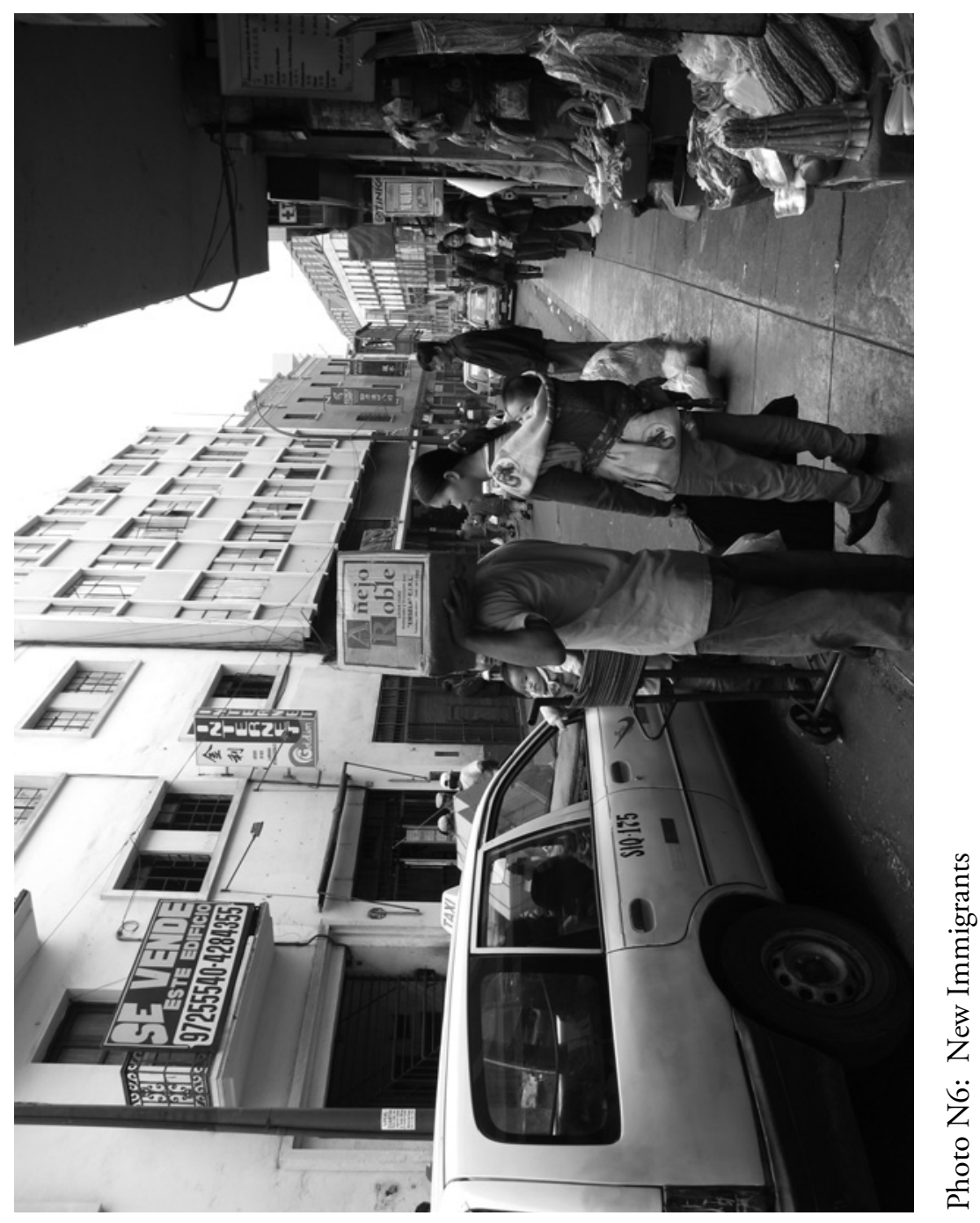


plastic to the most sophisticated electronic toys. The principal importers were the E. Wong supermarkets (owned by the president of the APCh) which sold 10.5 percent of the total imports, the big Chilean department stores, and Ripley and Saga Falabella. Then there were the importers of the Chinese quarter such as Commercial ARFRE (2.8 percent), Tay Loy (1.9 percent), Godiaz, Golden Empire, Part.P.Z, followed by a great number of small importers with less than 1 percent of the market. ${ }^{71}$ Actually at the same time that the Fujianese were trying to take over the toy market, the Peruvians in the heart of the Chinese quarter were becoming importers themselves. It is easy now for the non-Chinese to order from China directly from the factories of Shenzhen or Ningbo, with or without the help of specialized agencies. However, it is difficult to know the exact share of imports in the hands of Tusans and Chinese merchants.

As for jewellery and fashion accessories, the same department stores are the biggest buyers and distributors together with a big specialized market in the La Victoria district, called Gamarra, founded by Peruvians-Aymaras from the Andes. The Chinese quarter is supplied by the big Tusan and Chinese importers, often the same ones who also import the well-known fashion articles and costume jewellery. Felix Mode and Fenix Mode sell in Paruro Street only a small part of the merchandise imported by the Casa China opened in 2006 (Junín Street). In 2005-2006 this commercial Chinese enterprise imported 20.3 tons of plastic necklaces. ${ }^{72}$ Prudence Import, which opened in 2005, imported from Ningbo and Pusan $\$ 44,000$ worth of necklaces, imitation jewels, plastic bags, scarves, clothes, watches and electronic toys from Shanghai. Tian Ze Import whose owner is from Fuzhou specializes in synthetic stones. More than fifteen of these new businesses dealing in novelties, jewellery and clothing have been opened in the quarter despite two unfavorable factors: competition and lack of space to store the merchandise. In fact the problem exists for all the importers who never stop going from one street to another, to change, relocate and increase the number of their warehouses and even their sales locations. The only items for sale that have remained in the same location are the pharmaceutical products in the big building in Capón Center on Paruro Street. MRK Trading imports medicines wholesale while the Lam Lau Company in Huallaga Street has brought over from China since 1996 its own herbs and medicinal components as it imports from China the

\footnotetext{
${ }^{71}$ El Comercio 10/10/2007 and 10/11/2007.

72 SUNAT, Actualización de datos del importador; www.aduanet.gob.per, and Universidad del Perú.
} 
specialized machinery with which to encapsulate and break up ingredients. Besides medicines, one finds a complete range of para-pharmacy products such as surgical gloves, baby bottle nipples, toothpaste, preservatives and perfume. In 2009 the Importaciones ZIU brought to the Chinese quarter $\$ 112,287$ worth of these products from China, Malaysia and Taiwan.

The preceding is not a complete inventory - many other activities should be noted such as the distribution of Chinese cigarettes which is beginning to take on an importance, or that of alcohol - but it gives one an idea of the density of the commercial fabric with the headquarters of import houses, wholesalers' boutiques, the cramped premises of the small distributors and above all the entangled depots and warehouses which cannot keep up with the increase in the quantities of merchandise that are brought in. This, plus the arrival of the new Fujianese immigrants, has led to the explosion of the Chinese quarter. The new arrivals, besides looking for space, have not only entered into competition with the Cantonese but have also developed other kinds of work and gone into new sectors of activity.

\section{A New Chinese Quarter in the San Borja District?}

We have seen how the first departures were made from the Chinese quarter to the District of San Borja. ${ }^{73}$ Evidently that was the result of an improvement in the circumstances and rising aspirations of the enriched Chinese merchants. In the case of the Tusans, it was out of a necessity to join the Chinese Catholic community that was organized around a high school and new associations. In Lima, San Borja is regarded as the chosen quarter of the rich Tusans and rich Chinese and one can find ten or so families in each block. Sometimes the houses there are built discretely in Chinese architectural style. This residential area with landscaped urbanization but with no commercial center to begin with, was crossed by long flowering avenues, with a few scattered neighborhood stores run by Peruvian half bloods. For more than ten years the streets and avenues were thus protected from the installation of stores thanks to the strict rules and vigilance of the residents. The Fujianese restaurant owners were the first to set up in business there. It is difficult to know whether this is because other Chinese had already moved in as residents, or that San Borja, with its potential as a relatively wealthy quarter,

\footnotetext{
${ }^{73}$ In the 1970s San Borja began a new urbanization plan for the upper middle class. It was recognized as a district in 1983 .
} 
had the best conditions for the development of Asiatic restaurants of quality and diversity in cuisines: Fujian, Hebei, Sechuan, Shanghai and even Liaoning. The San Borja district because of its safe environments would be ideal for clients to go out at night, or organize family celebrations in good restaurants, something that has become impossible in the Chinese quarter. After ten years of perseverance, fifteen new Chinese restaurants were opened in 2000 and nine others ${ }^{74}$ in 2004. On the big avenues San Luis and Aviación, thanks to the perseverance of investors, the majority of whom being Fujianese, casinos, hotels and massage salons have multiplied. Other businesses such as internet kiosks, hairdressers and little bazaars selling products which one finds in the Chinese quarter have followed despite the high costs of real estate and rents. The Fujianese, finding the Chinese quarter too crowded, have thus moved their main business - the restaurants - to this district and implanted themselves here. They have also diversified. Chinese accounting offices, travel agencies, the bijuterias and stores of fashion articles have been set up here amidst the Mongolian and Cantonese restaurants. The S.B. Trading Co. which dominated the sale of food products with Chinese ingredients, the Moi Invert with its Villa Chicken rotisseries as well as other businesses have also followed the Fujianese to this district. Apart from the Fujianese, the Taiwanese also reside in this quarter together with the Cantonese of the former generations and Chinese executives from the northern provinces employed by the Chinese government.

By 1999 three grand avenues in San Borja had acquired the reputation of being "Chinese" which explains why the Beneficencia China - whose directors reside in San Borja and the neighboring residential quarters — organized on the occasion of the 150th anniversary of the Chinese presence in Peru a big parade of allegorical floats representing the different regional associations as well as the great Chinese enterprises together with a performance of the dance of the Dragon (put up by the Juan XXIII high school, the Zhongshan Huiguan and the Wong supermarkets). In April 2010, the Fujianese, still excluded from the leadership of the Beneficiencia, being tainted by their suspected involvement in more and more violent crimes perpetrated by the Chinese mafia especially in the trafficking of immigrants, ${ }^{75}$ finally provided their JLC.

${ }^{74}$ Survey Lausent-Herrera: Informe 446, Municipalidad de San Borja, 2005-MSB-GCJLC.

75 Pieke and Nyiri (2004: 146) has this to say concerning the Fujianese migrants in Budapest: "Migrants from Fujian, as newcomers associated with illegal migration and crime, are often stigmatized by other Chinese as a cohesive, closed and crime-prone group, an image often summed up with the term "Fuquing gang." The Fujianese in Peru have the same reputation. See also Jan Lin (1998: 50-54). 
association, officially created in 2008, with a real location outside the Chinese quarter ${ }^{76}$ in Canada Avenue, at the outskirts of the San Borja district and that of La Victoria. The rapid enrichment and the dynamism of what appears at present to be the Fujianese community is not to the taste of the Cantonese leaders. Neither are the expanding Chinese businesses which are starting to encroach upon the little streets outside the avenues to the taste of the residents.

For the moment this new Chinese "implantation" cannot be considered a new Chinese quarter as traditionally defined, i.e. it should be complete with the headquarters of its institutions, its temples, its restaurants and above all, its history. One can, however, speak of it as an extension or an enclave, insofar as one observes that there is "the maintenance of ethnic cultures and the development of ethnic business." ${ }^{\prime 7}$ However, it would be more appropriate to consider it as an extension, a satellite Chinatown in the making.

The phrase, "Rising out of Chinatown" as used by Min Zhou (1992: 185) may be applicable, as several authors have observed, to various Chinatowns such as in London or New York, but the case of Lima is different. First, unlike in the cases Zhou has cited, there have been no Chinese workers for a long time in the Chinese quarter in the center of Lima and there has not been gentrification of the town center or of the Chinese quarter. In Lima's Chinatown, the employees are Peruvians, or Tusans of modest means, or the new legal and illegal immigrants going through their period of adaptation and learning, sometimes tied to the owner of an establishment by a debt. Above them are the owners of the businesses and buildings, the Tusan and Chinese managers who had arrived before the new immigration of the 1980s. They are wealthier and, as has been said, they have other ambitions. The first group to leave consisted of the wealthiest and oldest of the Chinese and the Tusan residents in the downtown Chinese quarter. In this sense it may be compared to the departure of the "American-born second-generation Chinese of Manhattan." 78 The employee-residents of the most modest means stay on; one guards the house and spends the night there waiting for the return of the owners the following night. It would be more appropriate to compare this to the situation in Flushing and New York, with the moving in of the well-to-do Taiwanese Chinese into the full residential area followed by the Cuban Chinese and those from South America (Min Zhou 1992:190), the later comers

\footnotetext{
${ }^{76}$ Since the beginning of the 2000s the Fujianese have met in a commercial location in the Capón Market in Paruro Street.

77 See Luk Wai-Ki (2008: 284).

78 Jan Lin (1998: 107) argues that "residential out-movers are additionally motivated by preference for privacy and space; their outward geographic mobility, enabled by household savings, also reflects upward social mobility."
} 
replacing the earlier ones. But there the similarity ends, since the Taiwanese did not leave under the same circumstances as the "legitimate" inhabitants of the Chinese quarter and because the Chinese-Latinos cannot be compared to the Fujianese. One would like to be able to see a parallel in this move to the suburbs (Brooklyn or Queens) as discussed by Min Zhou (1992) and Jan Lin (1998:110), or to that of the first suburban Chinatown in London as described by Luk (2008), but the actors and the underlying reasons are not the same.

\section{Future Extensions of the Chinese Quarter}

When one speaks of the case of the Fujianese merchants leaving for the San Borja enclave, it would be more accurate to say that they have kept their activities as importers, wholesalers and retailers in the Chinese quarter while still going out to invest in a new space. Their presence in San Borja does not imply their retirement from the Chinese quarter. Moving a part of their commercial activities and their residence, followed by several well-advised Cantonese, does not in any way solve the problem faced by all the merchants of the Chinese quarter, which is a crucial lack of warehouses for their merchandise. The volume of imports never cease to increase, the small premises of the galleries and empty apartments serving as storerooms for the retailers are no longer sufficient. In the La Victoria district next to the Chinese quarter, the older merchants who make up a majority of the leaders of the Beneficencia have kept some warehouses in the old, inactive factories but those who aren't this lucky must disperse their merchandise among several warehouses.

The information furnished by the economic census of 2008 allows us to see how this problem has been solved by going far into the new zones of economic development in the emerging quarters which encircle the capital. In place of the old zones where law and order was non-existent and underequipped, these new districts which have several hundred thousand inhabitants have been modernized and have become the most enterprising new areas of expansion.

Going toward the northeast, the district of San Juan de Lurigancho ${ }^{79}$ offers numerous possibilities. With more than one million inhabitants, it is an enormous market. It is also a delocalization spot for some enterprises and private institutions (universities and colleges), industrial settlements especially

79 This district, the most densely populated in Peru, was created in 1967. It now has the emerging classes, a population evolving from street vendors to technicians and school teachers. 


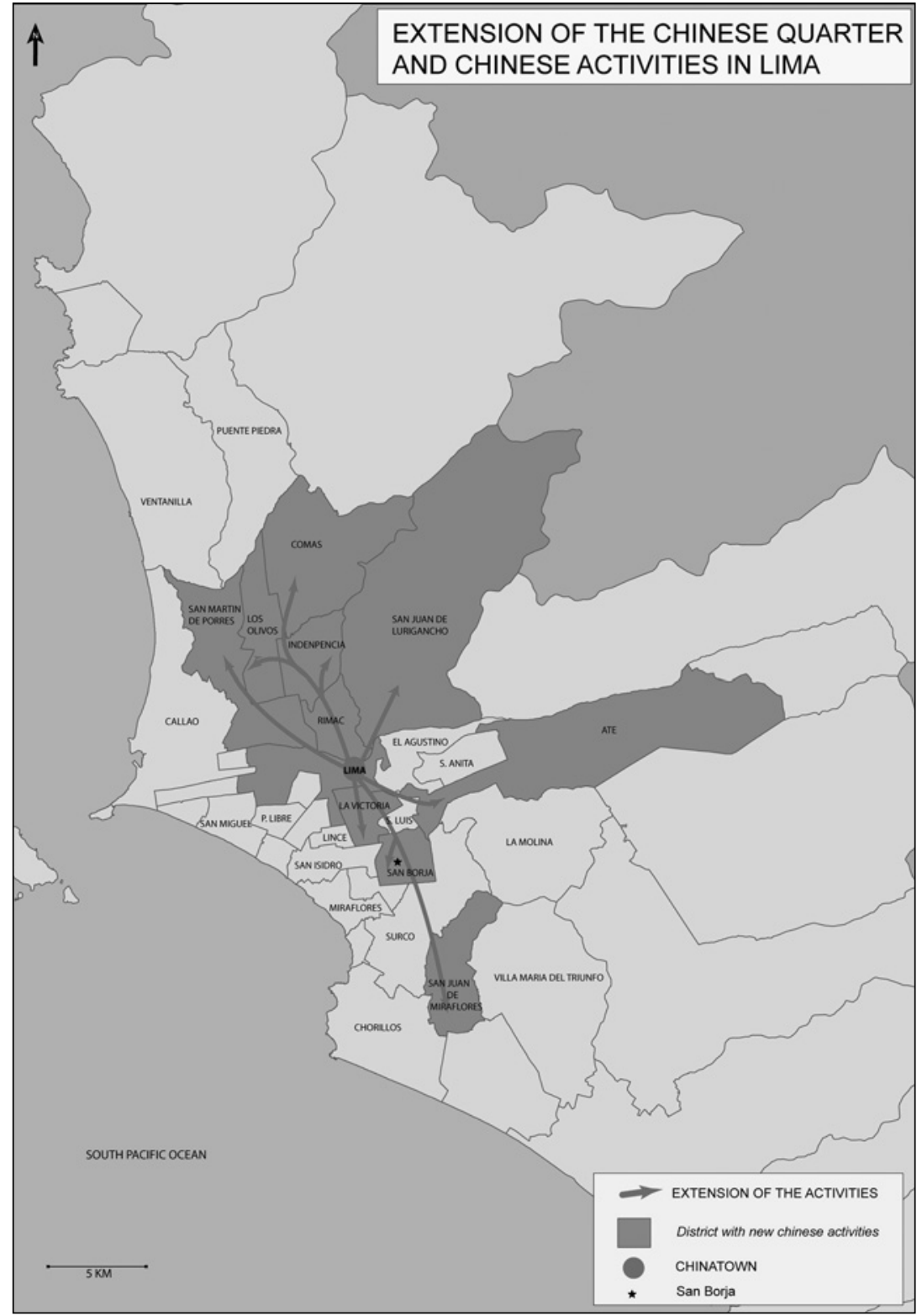

Map 2 
in the clothing industry, furniture factories and plastic packaging, ateliers for steel frameworks and wholesalers in jewellery and fashion accessories. It offers above all room for storage and warehouses in the Parque Zonal of Huiracocha, at the Customs office and in the industrial urbanization of Campoy. S.B. Trading stores its food products and alcohols there, as does Tay Long its imports of school supplies and paper products, and AJC.SA its hardware and imported fishing equipment. Fujianese importers of technopor insulating building material (Cia. Lim) are also installed there. In addition the Fujianese have opened there a number of inexpensive Chinese restaurants, often run by young immigrants waiting to leave for the United States, as well as hotels and casinos. The members of the Chinese Evangelical Church of Peru, concerned about the morality and the distress of the new immigrants who live and work there, go regularly to preach to the cooks and waiters of the restaurants in the evening after their work. ${ }^{80}$

Further north, the districts of San Martin de Porres and Los Olivos are very much sought after by the merchants of the Chinese quarter. One finds there the manufacture of latex balloons and "Delta" plastic by the Chinese import company "Fatima." The Tay Loy has its warehouses there, and Wah Fung, its noodle factory and several business managers installed in the Barrio chino live there. This district is full of promise and offers many advantages with several industrial zones, some very large commercial centers, such as Mega Plaza and Plaza Norte, warehouses for wholesalers and for construction material as well as a central bus station and a financial center for enterprises. Los Olivos, a residential district of the emerging middle classes, ${ }^{81}$ began to take off economically in 1995 just at the time when the Fujianese began to be interested and bought houses for their restaurants there. Between 2001 and 2003, 68 chifas were opened ${ }^{82}$ and since then the number has grown. After San Borja, this is the district most prized by the Fujianese who not only live but invest and work here. To the south, the Tai Heng company stores a part of its paper imports and school supplies in the district of San Juan de Miraflores. It possesses three other warehouses in the district of Ate. AteVitarte, a valley at the foot of the Andes, has also welcomed a number of Chinese who worked there before in the factories which have now disappeared. Chinese restaurants are also numerous in the area.

${ }^{80}$ On this theme, see Lausent-Herrera (2008).

${ }^{81}$ Los Olivos, formerly attached to San Martin de Porres, became a District in 1977 but was created politically in 1989. It has more than 300,000 inhabitants and is both residential and commercial with an industrial park, steelwork manufacturers of construction material, industrial mills and factories.

82 Relación general registrada de Chifas. Municipalidad distrital de Los Olivos. Unidad de gestión informática 2004. Survey by I. Lausent-Herrera. 
From the Chinese quarter in the heart of Lima a number of new immigrants have departed the majority of whom being Fujianese, in search of new space. During these last ten years, at least one thousand chifas, not counting the other businesses, have thus been opened in the emerging quarters, in tandem with the economic growth in Peru and the consolidation of the new middle classes. One may consider that these new implantations are also a form of extension of the Chinese quarter but, except in the case of Los Olivos, the space there is so big that regrouping in the form of a traditional Chinese quarter is not yet foreseeable; there is nothing at present which could really make one visualize a future Chinese quarters.

\section{Conclusion}

After the depressed period of the 1980s, the Chinese quarter has revived its economic dynamism and rediscovered its Chinese soul, thanks to the arrival of the new immigrants. But is the Chinese quarter still the same and if not, in what ways has it been changed by the new immigrants? Does it fulfill the same functions as before and above all is it still a "real" Chinese quarter? Finally, will the changes and the intensity of the exchanges lead to the reorganization of the quarter and along with it the whole of the Chinese community living in Peru? The explosion of the quarter, the possibility of future relocations, the diversification of the commercial activities as well as the reassembling of the new immigrants in outlying quarters: are they not the manifestations of a profound structural change? After analyzing the various signs of this change, one is drawn to the conclusion as follows.

For those who still live there or who have lived there for a long time, the quarter is of course not the same. The old Chinese are no longer there; they disappeared together with the Odeón Cinema, the former Chinese theater, the last opium dens and the old restaurants frequented by the intellectuals in the evening. In fact what one sees is not a change in the quarter in itself it has changed relatively little - but an acceleration of time, an extreme reduction of distances, which makes life in the quarter never the same again even if the new immigrants sleep in apartments which had been occupied by several generations of distant relatives before them. From the torpor of the 1980s we have gone into a whirlpool of transactions. There are many enterprises in the Chinese quarter, from one warehouse to another, one restaurant to another, and one gallery to the other. Even the Peruvians have begun to import and sell Chinese merchandise.

The only slowing down in this frenzy of exchanges may be the language. In the past Cantonese and Hakka, used to a long period of coexistence 
and united by marriage, understood each other. Now one must learn Putonghua if one wants to do business with the newcomers from Fujian who belong to several different dialectic groups, or trade with the latecomers from central and northeast China. For the older generations of Chinese, these elements of changes are fearsome because they reduce at the same time their cultural space and the physical space in which they move. The inevitable eviction of the Cantonese and the Hakka from the quarter is thus seen as an assumption of power by the newcomers.

In the quarter, the role and vocation of the huiguan have also been affected by globalization. Their function as a center of information and meeting place is no longer the same. It has been a long time since the new immigrants went to the Beneficencia or to the huiguans to have their letters written and sent to their families. Today cell phones and the neighborhood internet kiosks allow them to make calls to all parts of the world. The fetes and the little libraries managed by the huigans have been replaced by VCDs of the latest Chinese films and popular singers, sold in the boutiques. Sending money home is no longer done by the Beneficencia but by Western Union or other Chinese agencies attached to the nieghborhood Peruvian banks. The circulation of information concerning the family or commercial activities no longer depends on the institutions. Relations between institutions and the new immigrants have thus changed but the need for social life in the quarter has remained. It must now be satisfied by meeting with friends and family in the chifas, little gaming circles and having conversations on a bench. These changes have privileged the individual as economic actor to the detriment of community life.

The relations once loosened between the huiguans and the regional Chinese authorities have on the contrary been tightened again and intensified to the point that the huiguans once again play their role as chambers of commerce and agencies for the employment of capital and humans from Guangdong. In appearance they do not engage much in traditional activities, however, they are indispensable as always in ensuring Chinese enterprises having the necessary aid. This function, accompanied by privileges and economic compensations, still makes the office of community managers attractive.

On the whole the traditional institutions have let themselves be governed by economic considerations, leaving aside their vocation of providing aid. The creation of a new Fujian regional association not affiliated to Beneficencia China dominated by the Cantonese, shows the difficulty of placing the new immigrants into the heart of the Chinese population residing in Peru. The competition between Cantonese merchants and the new Fujian importers plus the independence of their associations have put into question the legitimacy and the representativeness of Beneficencia China for more than a 
century and a half from its headquarters on Paruro Street. There is no longer one single Chinese community always associated by the Peruvians with the Chinese quarter and the Cantonese, but several communities independent of and not obligatorily linked to the Chinese quarter.

Between 1993 and 2008, the years corresponding to the renewal of the migratory wave, the value and the volume of commercial exchanges with China increased considerably from $\$ 231,000,000$ to $\$ 7,800,000,000$ (Torres 2010). The merchandise, more and more diverse, has invaded the Chinese quarter, confirming in this way its commercial vocation while bringing on its explosion because of lack of space for sales and warehouses. The Cantonese have become less numerous and are well implanted in the quarter. The Fujians have thus been swept by the current of decentralization ${ }^{83}$ in transferring a part of their activities to the new emerging quarters. They and the late arrivals from the provinces of central and northern China are also installing their new chifas and restaurants of regional cuisine (breaking in this way with the Cantonese cuisine), their boutiques of Chinese imports (lamps, eyeglasses, clothing) and their spas, hotels and casinos all along the line of the future electric train linking the districts of the southern zone (Villa Maria del Triunfo) with those of the northern zone (San Juan de Lurigancho) as well as along the line reserved for the Metropolitano. ${ }^{84}$

Some years ago the Peruvians residents in the capital thought that one Chinese community - symbolized and materialized by the Chinese quarter and its Beneficiencia - lived in symbiosis. Today, the new migratory flow of Chinese from different provinces in China as well as the impressive waves of Chinese imports offered for consumption have made them realize that this quarter and this community which they once regarded as being "their" China, is in fact but a tiny part of China and its economic potential.

\section{References}

Ang See, Teresita. 2007. "Influx of new Chinese immigrants to the Philipines: Problems and challenges." In Beyond Chinatown. New Chinese Migration and the Global Expansion of China. Mette Thunø, ed. NIAS Studies in Asian Topic Series, 41. NIAS Press, pp. 137-62.

Balbi, Mariella. 1999. Los chifas en el Perú. Universidad San Martin de Porres. Lima.

${ }^{83}$ This mobility in effect coincided with the conquest by the supermarkets (first great importers and distributors of Chinese products) in the emerging quarters with their new middle class.

${ }^{84}$ In 2011, after twenty years of construction work, the Electric Train (Tren electrico) should be inaugurated. The Metropolitano bus is already running. These two new forms of mass transportation should be able to relieve the congestion in the metropolis. 
Bilu Zhonghua Tonghui Zongju, ed. 1986. Bilu zhonghua tonghui zongju yu Bilu huaren. Lima. Ceccagno, Antonella. 2007. "The Chinese in Italy at the Crossroads: The Economic Crisis." In Beyond Chinatown. New Chinese Migration and the Global Expansion of China. Mette Thunø, ed. NIAS Studies in Asian Topic Series, 41. NIAS Press, pp. 115-36.

Cisneros, Carlos and Rómulo Garcia. 1898. Geografía Comercial de América del Sud. Lima.

D’Ursel, Charles. 1889. Sud-Amérique. Plon, 4ème ed., Paris.

Herrera, Javier. (2003). "Perfiles de pobreza en Lima Metropolitana." Mimeo, Banque Mondiale. Kwong, Peter. 1996. The New Chinatown. NY: The New Press, Hill and Wang.

Lausent, Isabelle. 1980. "Constitution et processus d'intégration socio-économique d'une micro-colonie chinoise dans une communauté andine à la fin du XIX ${ }^{\text {Xèe }}$ siècle, Acos." Bulletin de l'Institut Français d'Etudes Andines IX, nº3-4, pp. 85-106.

Lausent-Herrera, Isabelle 1991. Pasado y Presente de la Comunidad japonesa en el Perú, Lima col. Mínima. IEP-IFEA. Lima.

. 1992. "La cristianización de los chinos en el Perú: integración, sumisión y resistencia." Bulletin de l'Institut Français d'Etudes Andines n 21(3), pp. 997-1007. Lima.

. 1994. "Lima au coeur de la ville, le quartier chinois." La Documentation Française nº 14 , pp. 311-19.

1996a. "Los caucheros y comerciantes chinos en Iquitos a fines del siglo XIX (18901900)." In Las raices de la memoria. América latina. Pilar Garcia Jordán et al., eds. Universitat de Barcelona, pp. 467-82.

. 1996b. "L'émergence d'une élite d'origine asiatique au Pérou." Caravelle $\mathrm{n}^{\circ}$ 67, pp. $127-53$.

- 1998. "Frentes pioneros chinos y desarrollo regional en la selva central del Perú." In $L a$ nacionalización de la Amazonia. Pilar Garcia Jordan y Nuria Sala y Vila, eds. Universitat de Barcelona, pp. 127-54.

. 2000. Sociedades y Templos chinos en el Perú. Fondo Editorial del Congreso, Peru.

. 2007. "Paroles de femmes dans l'immigration chinoise au Pérou." Diasporas, n 11, pp. 37-56. Toulouse.

- 2008. "La captación de la fe de los nuevos inmigrantes chinos y de sus hijos por las Iglesias Católica y Evangélica." In Políticas divinas: Religión, diversidad y Politica en el Perú contemporáneo. F. Armas Asin et al., eds. Instituto Riva-Agüero, Lima, pp. 123-51.

—. 2009a. "La nouvelle immigration chinoise au Pérou." Revue Européenne de Migrations Internationales. 25(1), pp. 71-96.

- 2009b. "Tusans (Tusheng) and the changing Chinese community in Peru." Journal of Chinese Overseas 5(1): 115-52.

Liang Zai and Hideki Morooka. 2004. "Recent Trends of Emigration from China, 1982-2000." International Migration. Vol. 42, Issue 3, pp. 145-64.

Lin, Jan. 1998. Reconstructing Chinatown: Ethnic Enclave, Global Change. University of Minnesota Press.

Luk, Wai-ki E. 2008. Chinatown in Britain. Diffusions and Concentrations of the British New Wave Chinese Immigration. Cambria Press.

McKeown, Adam. 1996. "La inmigración China al Perú, 1904-1937; Exclusión y negociación." Histórica Vol. XX n 1, July, pp. 59-91. Lima.

- 2001. Chinese Migrant Networks and Cultural Change. University of Chicago Press.

Ministerio de Gobierno Policía y Obras Públicas. 1878. Censo General de la República del Perú formado en 1,876, 7 tomos. Imp. del Estado. Lima.

Ministerio de Hacienda y Comercio, Dirección Nacional de Estadística. 1940. Censo Nacional de Población y Ocupación de 1940. 2 Volumes. Lima.

Muños, Fanny. 2001. Diversiones públicas en Lima. 1890-1920: la experiencia de la modernidad. Red para el desarrollo de las Ciencias Sociales en el Perú.

Pieke, Frank, Pál Nyíri, Mette Thunø and Antonela Ceccagno. 2004. Transnational Chinese. Fujianese Migrants in Europe. Stanford University Press. 
Pradier-Fodéré, Camille. 1897. Lima et ses environs. Paris: Pedone.

Siu, Kam Wen. 1985. El tramo final. Lluvia editoriales. Lima.

Torres, Victor. 2010. El TLC Perú-China: ;Oportunidad o amenaza? Lima: CEPES.

Wiener, Charles. 1880. Pérou et Bolivie, récit de voyage. Paris: Hachette.

Witt, Heinrich. 1987. Diario y Observaciones sobre el Perú, 1824-1890. Lima: Cofide.

Wong, Bernard. 1978. "A Comparative Study of the Assimilation of the Chinese in New York City and Lima, Peru." In Comparative Studies in Society and History, vol. 20, No 3 (July 1978), 335-58.

Zhou, Min. 1992. Chinatown: The Socioeconomic Potential of an Urban Enclave. Temple University Press.

\section{ANNEXS: Chinese Population in Peru according to Population Census 1941-2007}

Table 1: Chinese in Peru according to the Population Census 1941-2007

\begin{tabular}{lrcr}
\hline & Men & Women & Total \\
\hline 1941 & 10365 & 550 & 10915 \\
$1961^{*}$ & 5210 & 722 & 5932 \\
$1972^{* *}$ & & & 4057 \\
1981 & 1237 & 477 & 1714 \\
1993 & 2307 & 1421 & 3728 \\
2007 & 1911 & 1539 & 3450 \\
\hline
\end{tabular}

Source: Population Census

1961* Population with Chinese nationality.

1972** Population born in China including 242 naturalized individuals and 3,815 individuals that kept their Chinese nationality.

Table 2: Concentration of the Chinese Population in Lima, the Capital City

\begin{tabular}{lcccc}
\hline & Lima & Callao & $\begin{array}{c}\text { total } \\
\text { Lima+Callao }\end{array}$ & $\begin{array}{c}\text { Percentage over } \\
\text { total national }\end{array}$ \\
\hline 1941 & 6871 & 486 & 7357 & $67,4 \%$ \\
1961 & 3774 & 382 & 4156 & $70,1 \%$ \\
1972 & 2885 & 269 & 3154 & $77,7 \%$ \\
1981 & 1209 & 124 & 1333 & $77,8 \%$ \\
1993 & 2958 & 289 & 3247 & $87,1 \%$ \\
2007 & 2790 & 141 & 2931 & $85,0 \%$ \\
\hline
\end{tabular}

Source: Population Census 